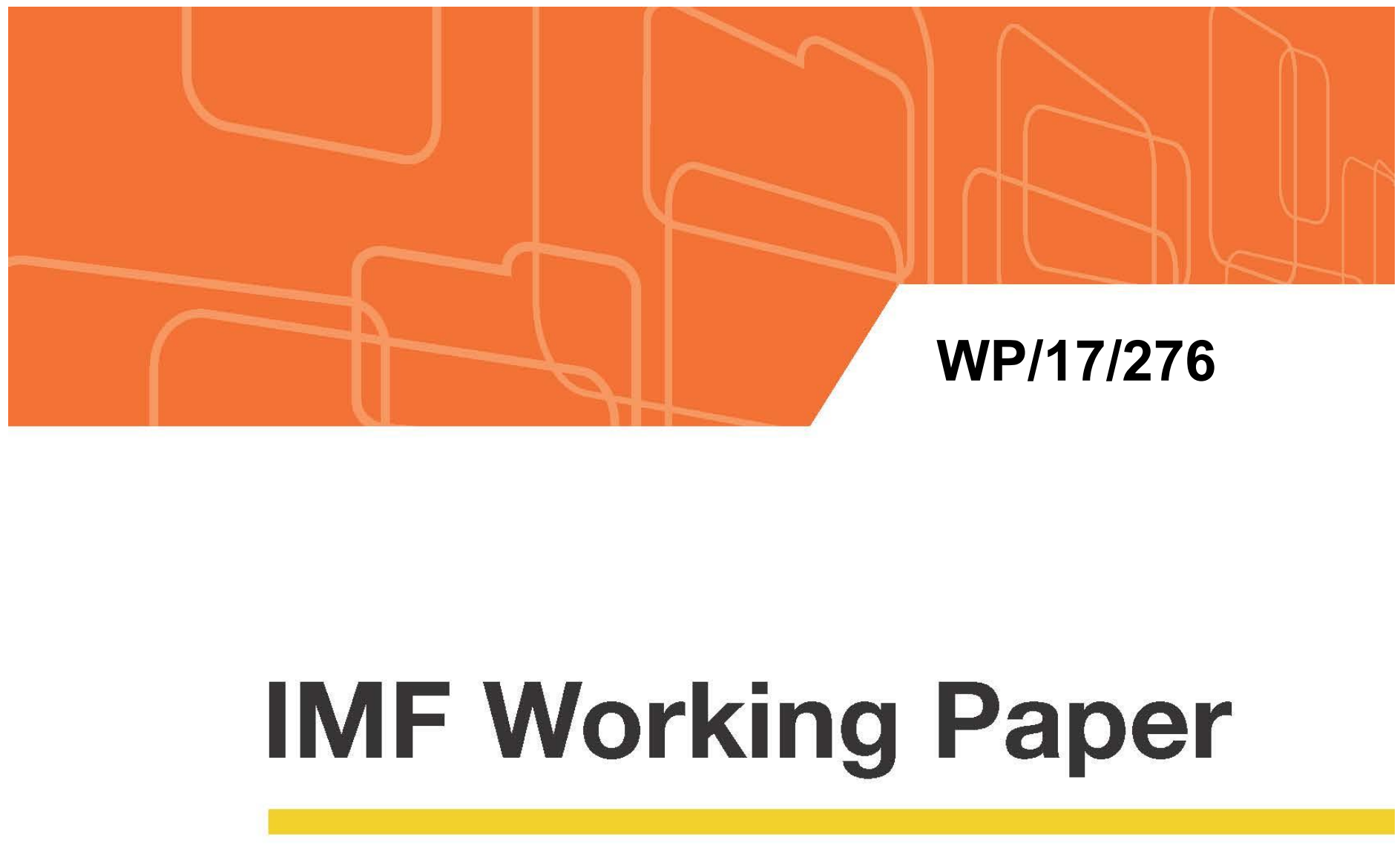

\title{
Identical Twins? Destination-Based Cash-Flow Taxes Versus Consumption Taxes with Payroll Subsidies
}

by Benjamin Carton, Emilio Fernandez-Corugedo, and Benjamin Hunt

IMF Working Papers describe research in progress by the author(s) and are published to elicit comments and to encourage debate. The views expressed in IMF Working Papers are those of the author(s) and do not necessarily represent the views of the IMF, its Executive Board, or IMF management. 


\title{
IMF Working Paper
}

Research Department

\section{Identical Twins? Destination-Based Cash-Flow Taxes Versus Consumption Taxes with Payroll Subsidies}

\section{Prepared by Benjamin Carton, Emilio Fernandez-Corugedo, and Benjamin Hunt ${ }^{1}$}

Authorized for distribution by Benjamin Hunt

December 2017

\section{IMF Working Papers describe research in progress by the author(s) and are published to elicit comments and to encourage debate. The views expressed in IMF Working Papers are those of the author(s) and do not necessarily represent the views of the IMF, its Executive Board, or IMF management.}

\begin{abstract}
The Global Integrated Monetary and Fiscal model (GIMF) is a multi-region, forward-looking, DSGE model developed by the Economic Modeling Division of the IMF for policy analysis and international economic research. This paper uses GIMF to illustrate when a destination-based cash-flow tax is equivalent to a combination of a consumption tax and a labor subsidy, as the latter combination have been advocated as proxies for the implementation of destination-based cash-flow taxes. The paper documents the conditions under which both types of taxes are identical and how the equivalence in terms of the real economy and tax revenue responses can be broken, namely after the introduction of finitely lived consumers that value government debt as net wealth (real economy) and the introduction of untaxed government expenditure (tax revenue).
\end{abstract}

JEL Classification Numbers: E12; E17; E52; E62; F41; F47

Keywords: tax policy; business taxation, financial accelerator, dynamic stochastic general equilibrium models; macroeconomic interdependence

Authors’ E-Mail Addresses:BCarton@imf.org;EFernandezCorugedo@imf.org; BHunt@imf.org.

\footnotetext{
${ }^{1}$ We would like to thank seminar participants at the International Monetary Fund, Federal Reserve and Bank of Canada. Jumi Kim provided excellent research assistance. All remaining errors are our own.
} 


\section{Table of Contents}

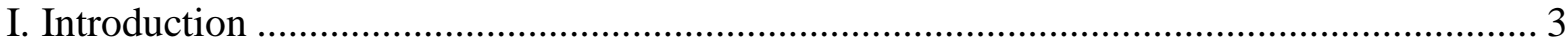

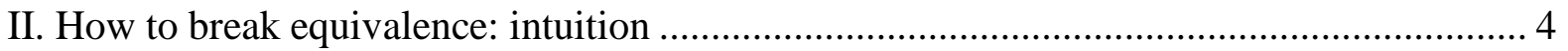

A. Cash-flow taxes create few distortions (without financial frictions) ............................. 6

B. Labor market equilibrium is distorted by consumption and labor taxes ....................... 6

C. OLG structure, household wealth and distortionary consumption and cash-flow taxes.. 7

III. Summary of the Global Integrated Monetary and Fiscal Model .................................... 8

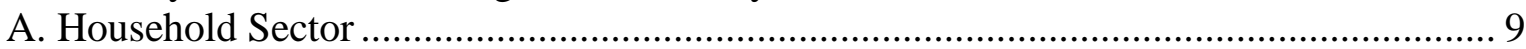

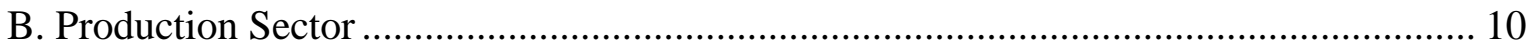

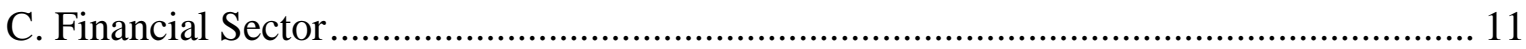

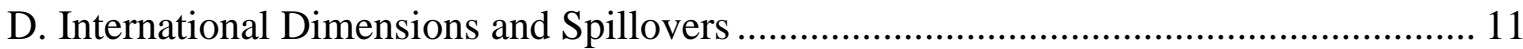

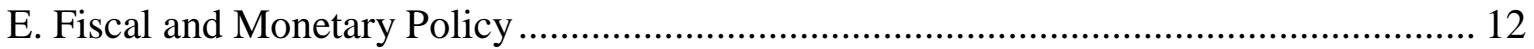

IV. On the equivalence between consumption and labor taxes and cash-flow taxes ............ 13

A. Full equivalence holds: Infinitely lived households and no government expenditure... 13

B. Breaking tax revenue equivalence: Infinitely-lived households with government

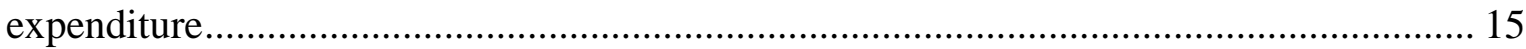

C. Breaking economic equivalence: Finitely-lived households and debt ........................ 16

1. Consumption taxes and government debt ...................................................... 16

2. DBCFT and CLS taxes with corporate debt ................................................ 17

D. Breaking economic equivalence again: when tax rates are non-zero to begin with ...... 18

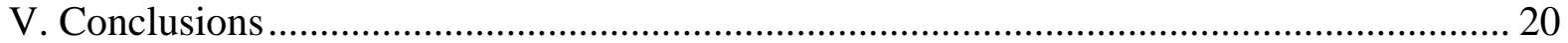

VI. References........................................................................................................ 21

Appendix I: A Simple Model to Examine Equivalence between CFTs and CLS ................ 23

Tables

Table 1. Tax Base Definitions ..............................................................................................23

Figures

Figure 1. Infinitely-Lived Households, No Government Expenditure ................................15

Figure 2. Infinitely-Lived Households, With Government Expenditure ...............................16

Figure 3. Finitely-Lived Households, With Government Debt .........................................17

Figure 4. Finitely-Lived Households, With Corporate Debt ..............................................18

Figure 5. Equivalence for Case 1 When Initial Tax Rates Are Not Zero ..............................20

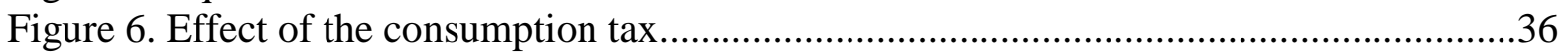




\section{INTRODUCTION}

Cash flow taxes (CFTs) have long ${ }^{2}$ been proposed as an alternative to corporate income taxes (CITs) since these can be shown to be less distortionary. The key benefit of a CFT relative to a CIT is that the former falls exclusively on rents and does not alter the economy's desired level of capital, whereas the latter (as do taxes on the return to capital) does so. Other noted advantages of the CFT relative to the CIT include the equal treatment of debt and equity capital under a CFT since the CIT allows for interest deductibility. ${ }^{3}$

However, the implementation of CFTs is not trivial. Proponents of the destination-based version of the cash-flow tax (DBCFT) suggest that they can be implemented via a valueadded tax (VAT) (or a consumption tax) and a payroll subsidy (or labor income subsidy), henceforth referred to as CLS. It is argued that implementing a CLS will be exactly equivalent to a DBCFT (see for example Auerbach (2017), Auerbach and others (2017) or Benzel and others (2017)). Such equivalence between the different taxes is typically stated with respect to the different tax bases, which strictly speaking, relates to "tax revenue" equivalence. It does not however, mean that the approximation of a DBCFT with the use of a CLS will deliver the same macroeconomic outcomes - "economic" equivalence. Yet despite not proving the existence of "economic" equivalence, proponents of the DBCFT typically present computations regarding the benefits of such a tax (tax reform that moves from a CIT to a DBCFT) by implementing a CLS.

In an open economy setting, the jurisdiction of different types of taxes is also important. Pure "source-based" taxes fall on both the domestic and foreign sources of revenues since these taxes are levied where production taxes place. A VAT or a consumption tax on the other hand falls on domestic (consumption) sales so these apply in the "destination" country where the sale takes place. A DBCFT, combines elements from the CFT and adds a destinationbased component. The destination-based component closely resembles a VAT in the sense that the tax only falls on domestic consumption and therefore excludes investment and exports but taxes imported consumption goods.

An important aspect of the implementation of the DBCFT as a CLS relates to many legal and political challenges (see the IMF's April 2017 Fiscal Monitor or Auerbach and others (2017)). The principal obstacle to the implementation of the DBCFT is that it would be incompatible with WTO rules. Hence one reason for implementing the DBCFT as a CLS is that the VAT also permits a border adjustment and is compliant with WTO rules (see Auerbach and others (2017) for more on this point).

\footnotetext{
${ }^{2}$ See Brown (1948) who first advocated the CFT, or the Meade Committee (1978), King (1987) for earlier calls in favor of CFTs.

${ }^{3}$ Auerbach and others (2017) provide an extensive description of the benefits of destination-based cash flow taxes. Box 1 of the April 2017 Fiscal Monitor also discusses some of the advantages of the destination-based cash flow tax.
} 
The aim of this paper is to show the conditions under which "full" equivalence, that is, "tax revenue" and "economic" equivalence between a DBCFT and the CLS holds. To do so, the latest version of the International Monetary Fund's Global Integrated Fiscal and Monetary (GIMF) model that incorporates a DBCFT (see Carton and others, 2017) is used. It is shown that "full" equivalence breaks down in certain cases. First, for "tax revenue" equivalence to hold, it matters whether government expenditure is subject to the consumption tax as the tax bases associated with a DBCFT and a CLS will otherwise differ. Second, and more importantly, "economic" equivalence will not hold if households treat government debt as net wealth, which occurs if households have finite lives and therefore discount the probability of having to pay the future tax liabilities associated with that debt. In this case, relative to the DBCFT, the consumption tax, which increases the consumption deflator and reduces the real value of government debt owned by households, creates a distortion that forces households to increase their saving. When households are infinitely lived, and do not value government debt as net wealth, the distortion is eradicated and the "economic" equivalence between a DBCFT and CLS holds.

This paper makes several contributions to the literature. First, it contributes to the literature that shows that CFTs can be less distortionary than other forms of taxation, by formally showing this through both a stylized small model and through GIMF simulations. Second, as noted before, it formally documents conditions under which DBCFTs are "economic" and "tax revenue" equivalent to a CLS. Previous research has primarily looked at "tax revenue" equivalence. Given this narrow focus, this literature typically appeals to many of the nondistortionary effects stemming from CFTs to advocate implementation via CLS, especially since much of the literature on consumption taxes/VAT has advocated that these are less distortionary than other forms of taxation. The third contribution of this paper, which is connected to the previous point, relates to the literature that has looked at the effects of consumption taxes in growth and general equilibrium models, and shows that consumption taxes are distortionary in an overlapping-generations framework.

The rest of the paper is structured as follows. Section II provides intuition for the conditions under which a DBCFT and a CLS are equivalent. Section III presents an overview of GIMF. Section IV presents the GIMF simulations. Section V concludes. An Appendix presents the simple model used to provide the intuition in Section II.

\section{HOW TO BREAK EQUIVALENCE: INTUITION}

This section provides an intuitive explanation for the conditions needed to guarantee "full" equivalence between a DBCFT and a CLS, exploiting the key equations of a simple overlapping-generations (OLG) model with endogenous labor supply (but no capital), based 
on Ascari and Rankin (2007). Appendix I provides more detail on this simple model, including the derivation of the key equations. ${ }^{4}$

Before presenting the key equations of the model, it is worth presenting the arguments typically used in the literature to advocate the equivalence between a DBCFT and a CLS. Auerbach (2017) and Benzel and others (2017) start from the national accounts expenditure definition:

$\mathrm{Y}=\mathrm{C}+\mathrm{Id}+\mathrm{G}+\mathrm{X}-\mathrm{M}$

where $\mathrm{Y}$ is GDP, $\mathrm{C}$ is private consumption, $\mathrm{Id}$ is domestic investment, $\mathrm{G}$ is government expenditure, $\mathrm{X}$ are exports and $\mathrm{M}$ are imports. On the income side of the national accounts:

$\mathrm{Y}=\mathrm{R}+\mathrm{W}$

where $\mathrm{R}$ are the returns to capital and $\mathrm{W}$ are the returns to labor. A DBCFT taxes domestic sales but permits expensing of investment and labor:

DBCFT Base $=\mathrm{Y}-(\mathrm{X}-\mathrm{M})-\mathrm{Id}-\mathrm{W}$.

Substituting (1) into (3) yields:

DBCFT Base $=\mathrm{C}+\mathrm{G}-\mathrm{W}$.

Hence a DBCFT "looks like" a CLS (a tax imposed on private sector and government consumption plus a subsidy for wage costs). Note that to generate the same revenues, the DBCFT tax rate should be the same as the consumption tax rate which in turn should have the same wage-subsidy rate. In practice, however, a consumption tax is not imposed on all forms of government consumption (e.g. national defense, law and order, education), so that a DBCFT does not generate the same amount of tax revenue as a CLS. This observation implies that the "tax revenue" equivalence may not hold in practice. Equivalence can therefore only be restored if either government consumption is subject to the consumption tax or if the DBCFT is only levied on private consumption sales:

DBCFT Base $=\mathrm{Y}-\mathrm{G}-\mathrm{Id}-(\mathrm{X}-\mathrm{M})-\mathrm{W}$,

where the introduction of $\mathrm{G}$ implies that only sales for final private consumption should be subject to the DBCFT. Note that these (tax revenue) equivalence claims hold for any tax base comprising total private consumption plus a subsidy to wage income. Hence, notwithstanding the discrepancies arising from the presence of government consumption, taxes on consumption (such as retail sales) and subsidies on labor income (such as labor income tax cuts) could also be used as instruments to approximate the DBCFT. Indeed, Auerbach (2017)

\footnotetext{
${ }^{4}$ The algebra presented in this section assumes that households do not hold money balances.
} 
notes that a similar point was made by Hall and Rabushka (1983) who advocated the use of consumption taxes and labor income cuts to generate efficiency. Exploiting these observation, in the simulations presented below, "full" equivalence is examined between a pure DBCFT and a CLS implemented via a consumption tax and labor income tax cut as those are the corresponding instruments in GIMF. ${ }^{5}$

\section{A. Cash-flow taxes create few distortions (without financial frictions)}

CFTs do not alter the firm's optimal choice of inputs for production (nor their relative prices) since the incidence of the tax falls on pure profits. ${ }^{6}$ Hence, optimal levels of production in the absence of the CFT will continue to be the same in the presence of the tax, implying that the firm's demand for capital and labor (and hence overall supply in the economy) is not affected by the tax. From a general equilibrium perspective, if the loss of dividend income stemming from the CFT is rebated back to consumers lump-sum, there will be no impact on the demand side either. These observations can be seen in the first-order conditions faced by the economic agents presented below.

\section{B. Labor market equilibrium is distorted by consumption and labor taxes}

Consumption and labor taxes affect households' (supply) and firms' (demand) first-order conditions. Consumption taxes create a wedge between the prices set by producers, $P$, which is the numeraire in the algebra below, and the prices faced by consumers, $P^{c}$ :

$P_{t}^{C} \equiv\left(1+\tau_{t}^{C}\right) P_{t}$

The presence of a consumption tax reduces the real wage received by consumers relative to the real producer wage (which is equal to the marginal product of labor) and induces an upward shift in labor supply. A payroll subsidy on the other hand generates a negative wedge between the labor costs faced by firms and the marginal product of labor, resulting in an outward shift of the labor demand schedule. ${ }^{7}$ The labor supply, demand and labor market equilibrium are shown by equations (6), (7) and (8):

\footnotetext{
5 The simple model used in this section considers a consumption tax plus a payroll subsidy (see the appendix for more). The key difference between using labor income taxes and payroll taxes is that the former affect labor supply whereas the latter affect labor demand.

${ }^{6}$ These arguments assume either a permanent change or constant tax rates. Carton and others (2017) show that temporary changes to CFTs can affect dividend and investment behavior since firms can take advantage of temporarily higher (lower) after-tax dividends by cutting (increasing) investment in response to temporary declines (increases) to the CFT.

${ }^{7}$ If the labor tax is levied on household's labor income rather than on payrolls, labor supply is affected, rather than labor demand. A labor income tax exacerbates the wedge between the (after-tax) real wage received by consumers and the producer real wage.
} 
$w_{t}=\vartheta\left(1+\tau_{t}^{C}\right) l_{t}^{\varepsilon-1}$,

$w_{t}=\frac{\alpha l_{s, t}^{\alpha-1}}{\left(1+\tau_{t}^{L}\right)}$

$l_{t}=\Gamma\left[\frac{1}{\left(1+\tau_{t}^{L}\right)\left(1+\tau_{t}^{C}\right)}\right]^{\frac{1}{\varepsilon-\alpha}}$,

where $w$ is the real producer wage (marginal product of labor), $l$ is labor, $\tau^{\mathrm{c}}$ is the consumption tax and $\tau^{\mathrm{L}}$ is the payroll subsidy, $\alpha$, and $\varepsilon$ are the labor demand elasticity and the (inverse of the) labor supply elasticity respectively and $\Gamma>0$ is a constant (that is a function of various structural parameters). Equation (8) shows that both taxes distort the labor market and reduce the quantity of labor. Such distortion can be eradicated if $\left(1+\tau_{t}^{L}\right)\left(1+\tau_{t}^{C}\right)=1$, that is, if a payroll tax subsidy is introduced that exactly offsets the impact of the consumption tax. In this case, the upward shift in labor supply is exactly offset by an outward shift in labor demand that results in the same amount of labor employed and the same after tax real wage as in the case of no taxes. ${ }^{8}$

Note that neither the labor demand or labor supply equations are affected by a CFT. The observation that the same amount of revenue can be raised with the same tax rates, Equation (3), plus the fact that distortions can be removed, is often used by proponents of the CFT as motive for approximating it with a via a CLS. However, this argument is a partial equilibrium argument that ignores other considerations that are now discussed.

\section{OLG structure, household wealth and distortionary consumption and cash-flow taxes}

With an OLG structure (based on Blanchard (1985) - Yaari (1965)), households treat government debt as net wealth. OLG households with finite-planning horizons know that the existing stock of government debt will be partly financed by taxes on agents that are yet to be born. Hence agents who hold government debt will not face the associated future tax increases fully and perceive government debt as being wealth. The presence of OLG households modifies the Euler equation for consumption (which determines the optimal consumption and savings decisions for households) which reads:

$a_{t}=\frac{1}{\left(1+r_{t}\right)} a_{t+1}+\Theta \frac{1-q}{1+\tau_{t}^{c}} v_{t}$

where $a$ is a variable that is proportional to consumption, $r$ is the real interest rate, $v$ is real household wealth (deflated by producer prices) which includes government debt, $q$ is the

\footnotetext{
${ }^{8}$ If instead of giving the firm a payroll subsidy, the labor income tax was cut by the same amount as the consumption tax was increased, the labor supply function would simply shift back to its original position leaving both employment and the after-tax real wage unchanged.
} 
probability of surviving into the next period and $\Theta>0$ is a parameter (comprising various structural parameters associated with household preferences and production technology). The key observation from (9), which is at the heart of the GIMF simulations presented below, is that real wealth enters the Euler equation when households have finite lives but vanishes under infinitely-lived representative households (where $q=1$ ). Equation (9) shows that all else equal, increases (declines) in real household wealth result in increases (declines) in consumption at time $t$. Using Ascari and Rankin's (2007) terminology, financial wealth (which includes government debt) serves as a store of value that facilitates consumption smoothing for a given time profile for total income (both labor and non-labor income). A (permanent) increase in the consumption tax, decreases the value of (consumer price deflated) real financial wealth, which in turn lowers current consumption. This channel is not present in the case where households are infinitely live.

An increase in the consumption tax, lowers the real value of household wealth. In response, households reduce their consumption and attempt to rebuild their wealth. Increased households saving reduces the real interest rate. In the simulations presented in Section IV, this mechanism is at the center of the results: higher consumption taxes reduce real financial wealth, lead households to rebuild their real financial wealth and leads to lower real interest rates, which eventually support investment and hence output. In an open economy setting, the additional saving results in a trade surplus. ${ }^{9}$

It is also possible to show why the CFT is equivalent to a lump-sum tax and why having a lump-sum tax rebate leaves household behavior unchanged. The resource constraint of the household (abstracting from money holdings for simplicity) is given by

$\frac{q}{1+r_{t}} v_{s, t}=v_{s, t-1}+w_{t} l_{t}+\left(1-\tau_{t}^{C F}\right) d_{t}-\tau_{t}^{L S}-\left(1+\tau_{t}^{C}\right) c_{s, t}$

where $\tau^{\mathrm{LS}}$ is a lump sum tax and $\tau^{\mathrm{CF}}$ is a cash flow tax levied on firms' dividends, $d$. Taxing dividends and rebating them exactly as lump-sum taxes, $\tau_{t}^{C F} d_{t}=-\tau_{t}^{L S}$ has no impact on the resource constraint of the OLG household. Hence CFTs are equivalent to a lump-sum tax.

\section{SUMMARY OF THE GLOBAL INTEGRATED MONETARY AND FisCAL MODEL ${ }^{10}$}

Before presenting the key simulation results, a summary of GIMF is presented. GIMF is a multicountry DSGE model with optimizing behavior by households and firms, and full intertemporal stock-flow accounting. Frictions in the form of sticky prices and wages, real

\footnotetext{
${ }^{9}$ Likewise, not directly captured in the simple model presented in the Appendix but captured by the simulations below, a CFT tax also reduces household real wealth which in terms of Equation (9), is equivalent to a reduction in $v$. This effect vanished when households are infinitely lived.

${ }^{10}$ For detailed documentation on the structure of the model see Kumhof and others (2010). For details on the model's properties see Anderson and others (2013).
} 
adjustment costs, liquidity-constrained households, along with finite-planning horizons of households, provide a role for monetary and fiscal policy in economic stabilization.

The assumption of finite horizons separates GIMF from standard monetary DSGE models and allows it to have well-defined steady states where countries can be long-run debtors or creditors. This allows users to study the transition from one steady state to another where fiscal policy and private saving behavior play a critical role in both the dynamics and longrun comparative statics. ${ }^{11}$

The non-Ricardian features of the model provide non-neutrality in both spending-based and revenue-based fiscal measures, which makes the model particularly suitable to analyze fiscal policy questions. Fiscal policy can stimulate the level of economic activity in the short run, but sustained government deficits crowd out private investment and net foreign assets in the long run. ${ }^{12}$ Sustained fiscal deficits in large economies can also lead to a higher world real interest rate, which is endogenous.

Asset markets are incomplete in the model. Government debt is only held domestically, as nominal, non-contingent, one-period bonds denominated in domestic currency. The only assets traded internationally are nominal, non-contingent, one-period bonds denominated in U.S. dollars that can be issued by the U.S. government and by private agents in any region. Firms are owned domestically. Equity is not traded in domestic financial markets; instead, households receive lump-sum dividend payments.

Firms employ capital and labor to produce tradable and nontradable intermediate goods. There is a financial sector a la Bernanke and others (2017) that incorporates a procyclical financial accelerator, with the cost of external finance facing firms rising with their indebtedness.

GIMF is multi-region, encompassing the entire world economy, explicitly modeling all the bilateral trade flows and their relative prices for each region, including exchange rates. The version used in this paper comprises of 3 regions with different calibrations for ease of exposition. The international linkages in the model allow the analysis of policy spillovers at the regional and global level.

\section{A. Household Sector}

There are two types of households, both of which consume goods and supply labor. First, there are overlapping-generation households (OLG) that optimize their borrowing and saving

\footnotetext{
${ }^{11}$ See Blanchard (1985) for the basic theoretical building blocks and Kumhof and Laxton $(2007,2009 \mathrm{~b})$ to understand their fiscal policy implications.

${ }^{12}$ Coenen and others (2010) show that GIMF fiscal multipliers for temporary shocks are similar to standard monetary business cycle models, but more importantly, GIMF can handle a much broader array of permanent shocks that can be used to study transitions from one steady state to another caused by permanent changes in the level of government debt.
} 
decisions over a 20-year planning horizon. Second, there are liquidity-constrained households (LIQ), who do not save and have no access to credit. All households pay direct taxes on labor income, indirect taxes on consumption spending, and a lump-sum tax.

OLG households save by acquiring domestic government bonds, international U.S. dollar bonds, and through fixed-term deposits. They maximize their utility subject to their budget constraint. Aggregate consumption for these households is a function of financial wealth and the present discounted value of after-tax wage and investment income. The consumption of LIQ households is equal to their current net income, so their marginal propensity to consume out of current income is unity. A high proportion of LIQ households in the population would imply large fiscal multipliers from temporary changes to taxes and transfer payments.

For OLG households with finite-planning horizons, a tax cut has a short-run positive effect on output. When the cuts are matched with a tax increase in the future, to leave government debt unchanged in the long run, the short-run impact remains positive, as the change will tilt the time profile of consumption toward the present. In effect, OLG households discount future tax liabilities at a higher rate than the market rate of interest. Thus, an increase in government debt today represents an increase in their wealth, because a share of the resulting higher taxes in the future is payable beyond their planning horizon. If the increase in government debt is permanent (tax rates are assumed to rise sufficiently in the long run to stabilize the debt-to-GDP ratio by financing the higher interest burden) this will crowd out real private capital by raising real interest rates. ${ }^{13}$

Increases in the interest rate have a negative effect on consumption, mainly through the impact on the value of wealth. The intertemporal substitution effect from interest rate changes is moderate and has been calibrated to be consistent with the empirical evidence. The intertemporal elasticity of substitution determines the magnitude of the long-run crowding-out effects of government debt since it pins down how much real interest rates have to rise to encourage households to provide the required savings.

\section{B. Production Sector}

Firms produce tradable and nontradable intermediate goods. They are managed in accordance with the preferences of their owners, finitely-lived households. Thus, firms also have finiteplanning horizons. The main substantive implication of this assumption is the presence of a substantial equity premium driven by impatience. ${ }^{14}$ Firms are subject to nominal rigidities in price setting as well as real adjustment costs in labor hiring and investment. They pay capital income taxes to governments, wages to all households, and dividends to OLG households.

\footnotetext{
${ }^{13}$ For a more detailed description of fiscal implications in GIMF see Kumhof and Laxton (2007, 2009a, 2009b).

14 This feature would disappear if equity was assumed to be traded in financial markets. The assumption of myopic firm behavior, and the resulting equity premium, are more plausible.
} 
Retained earnings are insufficient to fully finance investment, so firms must borrow from financial intermediaries. If earnings fall below the minimum required to make the contracted interest payments, the financial intermediaries take over the firm's capital stock, less any auditing and bankruptcy costs, and redistribute it back to their depositors (households).

Firms operate in monopolistically competitive markets, and thus goods' prices contain a markup over marginal cost. Exports are priced to the local destination market and imports are subject to quantity adjustment costs. There are also price adjustment costs which lead to sticky prices.

Firms use public infrastructure (which is the government capital stock) as an input, in combination with tradable and nontradable intermediate goods. Thus, government capital adds to the productivity of the economy.

\section{Financial Sector}

GIMF contains a limited menu of financial assets. Government debt consists of one-period bonds denominated in domestic currency. Banks offer households one-period fixed-term deposits, their source of funds for loans to firms. These financial assets, as well as ownership of firms, are not tradable across borders. OLG households may, however, issue or purchase tradable U.S.-dollar-denominated obligations.

Banks pay a market rate of return on deposits, and charge a risk premium on loans. Because of the costs of bankruptcy (capital can only be liquidated at a discount), the lending rate includes an external financing premium, which varies directly with the debt-to-equity (leverage) ratio - the financial accelerator effect. Non-linearities imply steep increases in the risk premium for large negative shocks to net worth.

Uncovered interest parity may not hold, due to the presence of country risk premiums. The premiums can create deviations, both in the short run and the long run, between interest rates in different regions, even after adjustment for expected changes in exchange rates.

\section{International Dimensions and Spillovers}

All bilateral trade flows are explicitly modeled, as are the relative prices for each region, including exchange rates. These flows include the export and import of intermediate and final goods. They are calibrated in the steady state to match the flows observed in the recent data. International linkages are driven by the global saving and investment decisions, a by-product of consumers' finite horizons. This leads to uniquely defined current account balances and net foreign asset positions for each region. Since asset markets are incomplete, net foreign asset positions are represented by nominal non-contingent one-period bonds denominated in U.S. dollars. 
Along with uncovered interest parity, and long-term movements in the world real interest rate, the magnitude of the international trade linkages is the main determinant of spillover effects from shocks in one region to other regions in the world.

\section{E. Fiscal and Monetary Policy}

Fiscal policy is conducted using a variety of expenditure and tax instruments. Government spending may take the form of either consumption or investment expenditure, or lumpsum transfers to either all households or targeted towards LIQ households. In previous versions of GIMF, revenue accrued from the taxes on labor income and capital returns, consumption taxes, and lumpsum taxes. The latest version of GIMF (Carton and others, 2017) also allows revenue to accrue from corporate income and, crucially from cash flow taxes which also permit a destination-based component (DBCFT). A CFT taxes the cash flows of corporates from sales after deducting the cost of labor, investment, and intermediate inputs. Under a DBCFT, revenues from exports are not subject to tax, while the cost of imports cannot be deducted, both of which relate to the destination based component of the tax. Carton and others (2017) document all the changes that were made to introduce CFTs as well as other corporate taxes. ${ }^{15}$

GIMF also allows for tariffs on imported goods to be a potential source of public revenue. Government investment spending augments public infrastructure, which depreciates at a constant rate over time.

There is a fiscal policy rule which ensures long-run sustainability, while allowing for shortrun counter-cyclical policies. Changes in both labor and capital income taxes provide the instrument to put the rule into effect, but this can be replaced with other tax, transfer or spending instruments if that is considered more realistic for a specific region. First, the fiscal rule ensures that in the long run, the government debt-to-GDP ratio - and hence the deficitto-GDP ratio - eventually converges to its target level. This excludes the possibility of sovereign default, as well as the risk that out-of-control financing requirements of the government will override monetary policy. Second, the rule allows for countercyclical fiscal policy as it embodies automatic stabilizers.

\footnotetext{
15 An important disclaimer pertains to the assumptions made when introducing the corporate taxes in GIMF (Carton and others (2017)), which were driven by the existing structure of GIMF and by the need to simplify the computational burden of solving the model. Thus, several channels that could affect the macroeconomic outcomes following changes in these taxes are omitted. For instance, one may expect to find that multinational firms may modify transfer prices, relocate patents, change their financial structure, or relocate production towards the country with the less distortionary tax system. In addition to the broad macroeconomic implications, the resulting tax-base shifts could potentially have large implication for corporate tax revenue in different countries. However, because the model's framework does not incorporate multinational firms, these potential transmission channels are absent. Additionally, owing to simplifying assumptions related to the currency denomination of foreign liabilities, the model-based analysis cannot capture the balance sheet effects of exchange rate movements.
} 
When conducting monetary policy, the central bank uses an inflation-forecast-based interest rate rule. The central bank varies the gap between the actual policy rate and the long-run equilibrium rate to achieve a stable target rate of inflation over time.

\section{ON THE EQUIVALENCE BETWEEN CONSUMPTION AND LABOR TAXES AND CASH-FLOW TAXES}

This section presents simulations that compare the macroeconomic impact of introducing a DBCFT vs introducing a CLS (consumption tax plus a labor income subsidy). The simulations are undertaken in a three-region version of GIMF, though Country A is assumed to represent roughly 95 percent of world output. ${ }^{16}$ Unless stated otherwise, the following assumptions are made in all experiments. First, a version of GIMF without a financial accelerator is used. Second, it is assumed that no distortionary taxes (consumption, labor, capital) are in operation (they are set to zero) and any tax revenue is raised via (nondistortionary) lump-sum taxes. Third, the external sector is assumed to be in equilibrium (the net foreign asset position is assumed to be zero) and there is no government budget deficit. Fourth, the introduction of the DBCFT or the CLS is implement only in country A, without similar implementation elsewhere. More specifically, country A introduces a DBCFT at a rate of 10 percent and the equivalent CLS is achieved by the introduction of a consumption tax of 10 percent with a labor income subsidy also of 10 percent. Fifth, the additional revenue raised by the taxes is rebated back to OLG households as a (non-distortionary) lump-sum transfer.

\section{A. Full equivalence holds: Infinitely lived households and no government expenditure}

This simulation further assumes that first, agents are almost infinitely lived and that there is no population growth (so Ricardian equivalence holds), ${ }^{17}$ second, that there is no government expenditure ( $\mathrm{G}$ in the context of Equation (1)) and third, that there is no government debt. The long-run (or steady-state) macroeconomic impact of the DBCFT vs. the CLS implementation is shown in Figure 1 and is labelled Case 1, which presents the impact on key variables. The impact of the DBCFT is shown in the solid blue bars, whereas that of the CLS is shown in the bars with stripes.

A DBCFT comprises two components, a CFT plus the destination-based component. A permanent increase in the CFT that is rebated lump-sum to OLG households does not create any distortions in the long-run. There is no impact on the labor market (both labor supply and demand) nor on the firms' desired level for the capital stock or investment, so that there is no negative impact on the level of output. The lack of effect on investment arises because the

\footnotetext{
16 The simulations are meant to be illustrative. Changing the size of country A to be a small open economy does not change the qualitative nature of the results being presented, but it changes the quantitative nature.

${ }^{17}$ It is not possible to numerically solve the model if agents are infinitely lived, so it assumed that households live for 900 years, which in the notation of equation (9) implies a value of q that is very close to 1.
} 
full deduction of investment expenditure from the firm's tax base implies that the required return to capital is not taxed and the tax falls only on rents. When the firm can fully deduct investment expenditures its tax liability is lowered by the tax rate times the amount invested and this is exactly equal to the net present value of future taxes the firm will pay on the component of their revenue stream that includes the required return to capital.

The destination-based component of the cash-flow tax has implications for the real exchange rate only. Under a destination-based system, only domestic sales (including imports) are taxed. Sales of exporting firms in foreign markets are not taxed at all under a destinationbased system. However, intermediate goods and other domestic input costs give the right to a tax deduction. Therefore, exporting firms receive a tax benefit from their foreign sales under a destination-based system (relative to a source-based system). Under monopolistic competition, this benefit is eventually passed-through into a lower export price in the longrun. For the importing firm, however, the cost of imported intermediate inputs is no longer deductible form their tax base. Hence, the price of a good entering the country that is imposing the destination based-tax is increased by the tax as it enters the country. Thus, the destination-based component of the tax reproduces the price implications of a depreciation of the exchange rate. Maintaining balance in the current account and thus the desired holdings of net foreign assets requires a compensatory real appreciation of the currency which is achieved via a nominal appreciation.

Rather than acting through firms, as was the case of the DBCFT, the CLS combines the impact of a consumption tax increase but with a labor income subsidy and works through households. With just an increase to the consumption tax, the level of consumption immediately declines, as well as private saving. Households work less as they decide to consume more leisure given that the return to labor effort has declined. The negative impact of the increase in the consumption tax more than offsets any increased incentives coming from firms increasing the real wage to induce more labor supply. Therefore, aggregate demand falls. On the other hand, the reduction in the labor income tax rate results in higher after-tax labor income which incentivizes households to work more and consume less leisure, thereby fully offsetting the impact of the consumption tax hike. The offset leaves labor supply and after-tax real wages unchanged and hence results in unchanged consumption and investment. There is therefore no overall impact of the CLS on output. Whilst the nominal exchange rate is unchanged in response to the CLS, the real exchange rate (headline CPI based) appreciates since the increase in the consumption tax acts to increase the price of consumption goods, though the terms of trade remain unchanged. 
Figure 1: Infinitely-Lived Households, No Government Expenditure

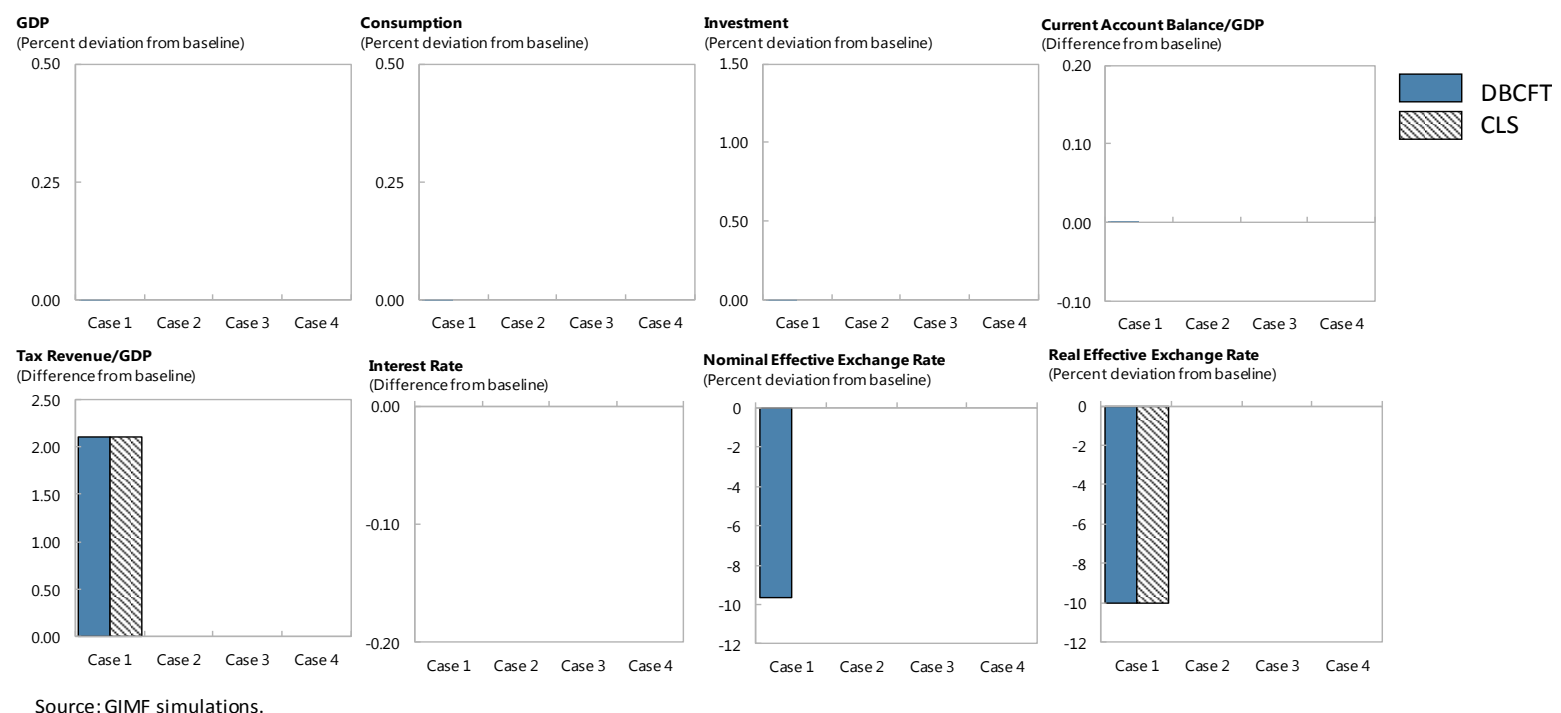

If government debt is always zero, there is no government expenditure, tax revenues are fully rebated to infinitely-lived households, and there are no other distortionary taxes in operation, full equivalence between DBCFT and CLS holds. This even extends to the case of finitelylived OLG households and no government debt. Equivalence holds because when there is no government debt, any increase in the consumption tax will not reduce the stock of real household financial wealth. This is equivalent to saying that $v=0$ in Equation (9). ${ }^{18}$

\section{B. Breaking tax revenue equivalence: Infinitely-lived households with government expenditure}

For these simulations, it is assumed that government expenditure represents around 20 percent of GDP, but government debt remains at zero percent of GDP. The introduction of government expenditure, which is not assumed to be subject to the consumption tax (because it would include things like national defense, law and order, and education), makes the tax bases associated with the DBCFT and the CLS different, thereby breaking "tax revenue" but not "economic" equivalence, as shown in Figure 2, Case 2.19

\footnotetext{
${ }^{18}$ In GIMF, OLG households accumulate government and corporate debt (stocks) and receive (after-tax) dividend payments from corporate profits (flows). While government and corporate debt is held by cohorts that are currently alive (future cohorts will have to buy them from currently living cohorts to build their financial wealth), dividend receipts are equally shared by current and (yet to be born) future cohorts. This implies that redistribution effects (which break Ricardian equivalence) between current and future generations are present with government and corporate debt, but not with dividend payments.

${ }^{19}$ In GIMF, the government purchases goods and services that are produced solely by the private sector, who is subject to the various corporate taxes. The government is not assumed to produce any goods or services.
} 
Figure 2: Infinitely-Lived Households, With Government Expenditure

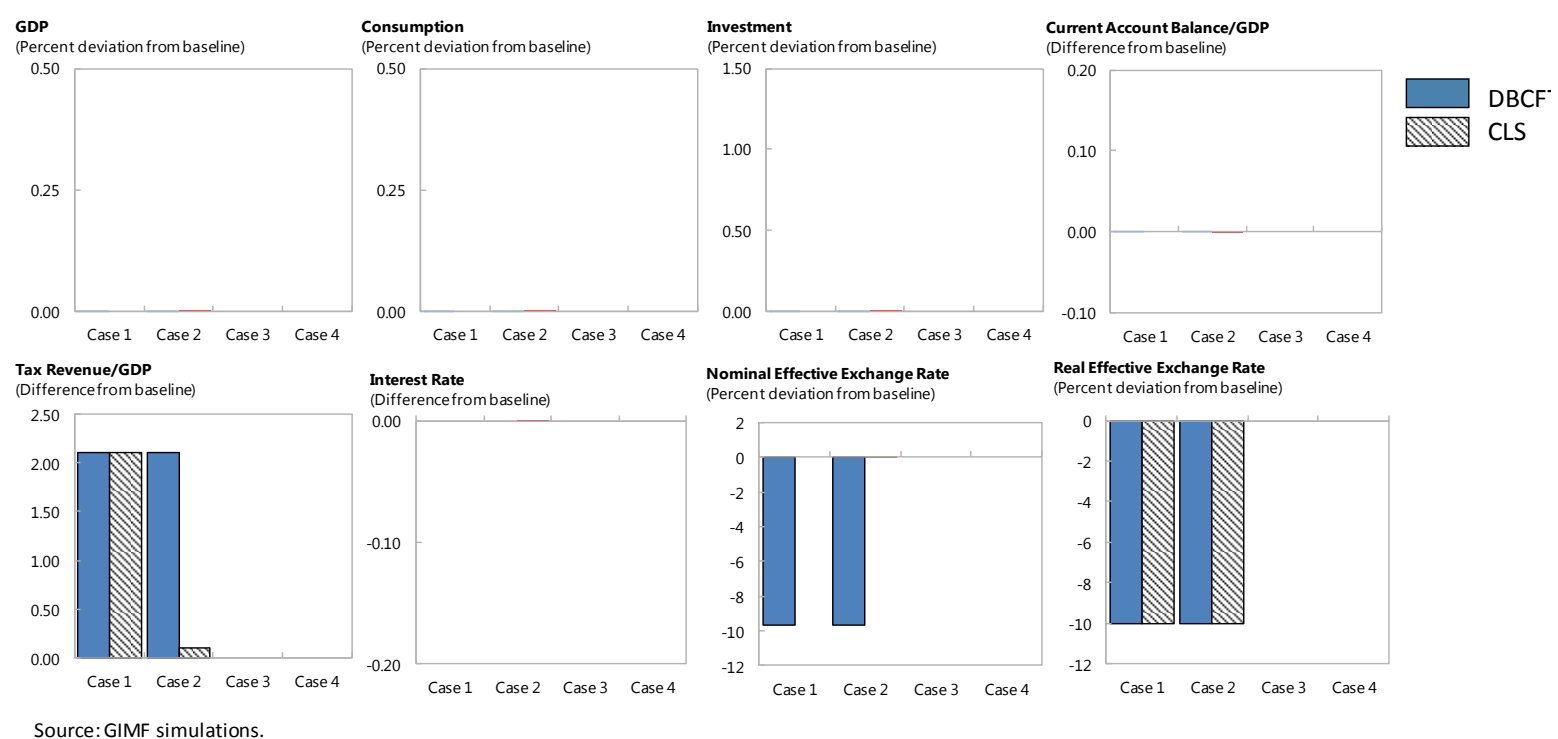

The reason why "economic" equivalence remains is the same as in Case 1: the consumption tax increase and labor income tax offset leave labor supply unchanged and do not distort the supply side of the economy, whereas the demand side is not affected since infinitely-lived households do not value government debt.

\section{Breaking economic equivalence: Finitely-lived households and debt}

In the next two simulations, it will be shown that "economic" equivalence can be broken in the presence of finitely-lived households and debt. In both simulations, government expenditure is assumed to be zero (so tax equivalence is satisfied) and all additional tax revenue is rebated back to OLG households as a lump-sum transfer. The simulations with government debt continue to assume that the financial accelerator block of GIMF is not operational, but for the simulations with corporate debt this block is active.

\section{Consumption taxes and government debt}

The case where finitely-lived households value government debt is presented in Figure 3, Case 3. In this case, economic equivalence is broken. The transmission mechanism of the DBCFT is the same as that discussed earlier. The DBCFT with transfers rebated back to OLG households as a lump-sum transfer and no initial distortionary taxes is itself not distortionary in the long-run. The only real variable affected in the long run is the real exchange rate which appreciates. The CLS however is distortionary, in the sense that all real variables are affected by the CLS implementation. The distortion arises from the consumption tax component of the CLS. The increase in the consumption tax raises the consumption deflator and lowers the real value of government debt and hence household real wealth. In response, OLG households increase saving, which acts to reduce the real interest rate. The reduction in the real interest rate raises investment, capital and hence output. 
Additionally, there is an improvement in the current account balance stemming from the additional household saving.

Figure 3: Finitely-Lived Households, With Government Debt

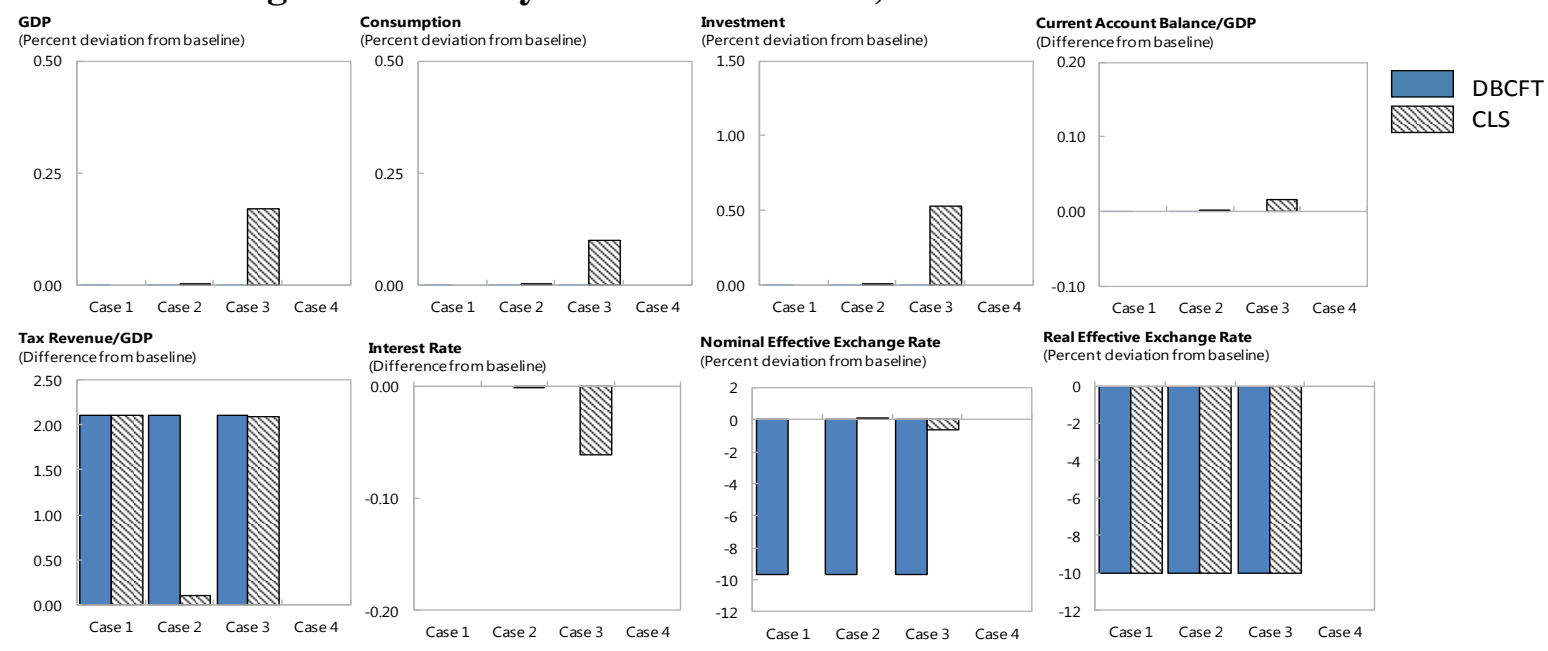

Source: GIMF simulations.

\section{DBCFT and CLS taxes with corporate debt}

In this simulation, government debt is again set to zero, but corporate debt is part of households' wealth. In response to a DBCFT, there is a change in the value of firms and the level of corporate debt. ${ }^{20}$ Because the dividend stream produced by firms is lowered by the tax, the value of the firm falls. With a smaller balance sheet to finance, firms need to borrow less and corporate borrowing declines. The change in the value of the firm and the associated decline in corporate debt outstanding reduces household financial wealth prompting them to save more. Higher saving in a large economy lowers the global real interest rate. This acts to support investment and hence capital accumulation. Higher household saving is reflected in an increase in the current account balance.

With the CLS, the channel at play is like the one described when there is government debt. The consumption tax component of the CLS reduces the real value of corporate debt and hence households' real wealth. In response, OLG households increase their saving which acts to reduce the real interest rate. The reduction in the real interest rate raises investment, capital and hence output. Again, higher household savings is reflected in an improvement in the current account balance. These impacts are all larger under the CLS than under the DBCFT.

\footnotetext{
${ }^{20}$ See Carton and others (2017) for more details on this experiment.
} 
Figure 4: Finitely-Lived Households, With Corporate Debt

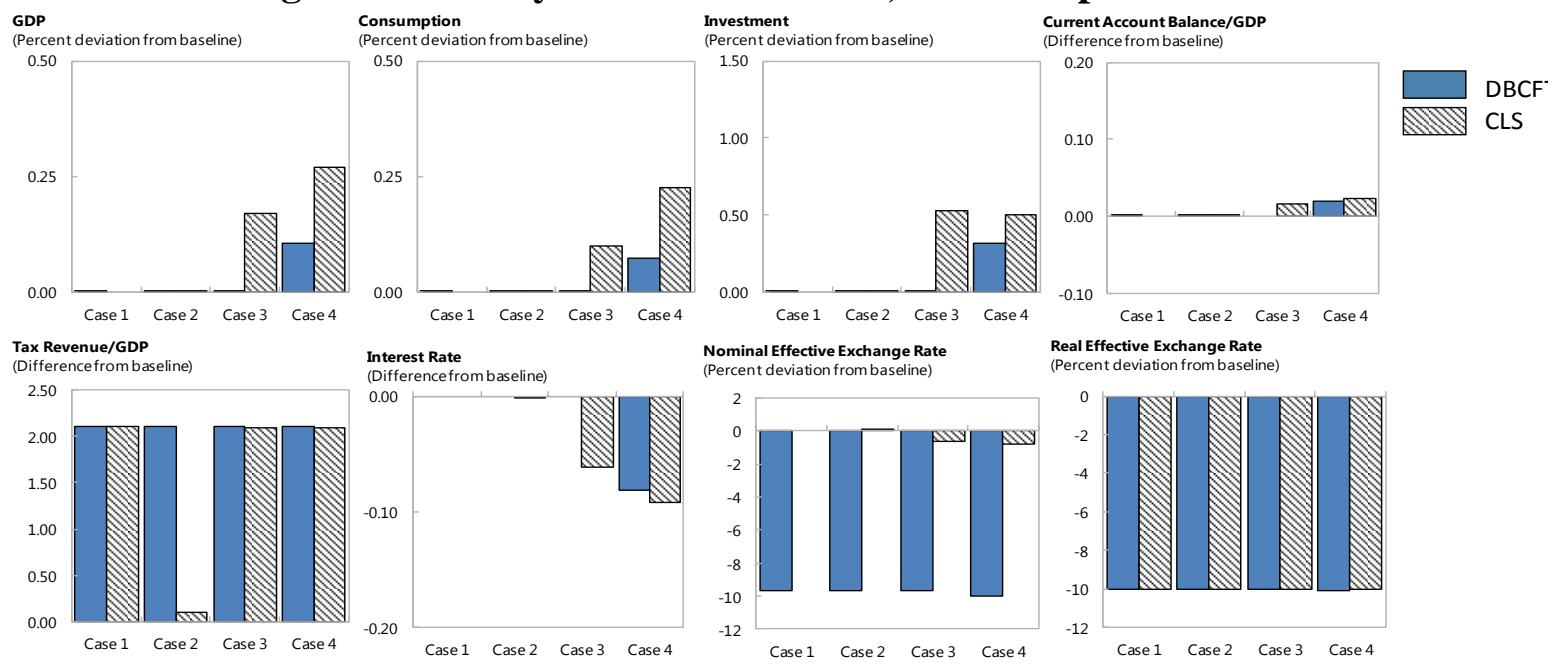

Source: GIMF simulations.

\section{Breaking economic equivalence again: when tax rates are non-zero to begin with}

There is another case where equivalence between a DBCFT and a CLS does not hold, even in the presence of infinitely-lived households: when existing (distortionary) tax rates are not zero. In this section, two further experiment are presented and compared to Case 1 above. In the first experiment (Case $1 \mathrm{Alt}$ ) consumption and labor income tax rates are assumed to be different from zero, whereas in the second experiment consumption, labor income and corporate income tax rates (CIT) are assumed to be different from zero (Case 1 Alt CIT). The value of the initial tax rates is calibrated to match OECD average tax revenues as a percent of GDP for consumption taxes (including excise duties), labor income taxes, and corporate income taxes. This yields rates of roughly 12 percent for the consumption tax, 32 percent for the labor income tax, and 10 percent for the business income tax. The simulations are presented in Figure 5.

Under Case 1, both the DBCFT and CLS were equivalent and non-distortionary (with no impact on real variables other than the exchange rate). As Figure 5 shows, even with infinitely-lived agents, the CLS is neither "tax revenue" nor "economically" equivalent and it has an impact on all real variables under both cases (Case 1 Alt and Case 1 Alt CIT). The DBCFT, however, only has an impact on real variables when corporate tax rates are non-zero (Case Alt CIT). To better understand why the CLS has an impact on output, it is useful to start with the condition needed to eliminate the distortions from both the consumption and labor taxes. In GIMF, the restriction is: 
$\frac{\left(1-\tau^{L}\right)}{\left(1+\tau^{C}\right)}=1$

which is not satisfied since the initial level of taxes is such that $\tau^{L}=0.32>\tau^{C}=0.12$ and hence the ratio in (11) is less than one so that the combination of both taxes depresses labor supply and hence output relative to the case where there are no taxes. Applying an increase of 10 percentage points for consumption taxes and a decline in labor income tax of 10 percentage points, $\Delta \tau^{C}=\Delta \tau^{L}=0.1$, results in a ratio that whilst still below 1 , is greater than the ratio under the initial tax rates:

$\frac{\left(1-\tau^{L}\right)}{\left(1+\tau^{C}\right)}<\frac{\left(1-\tau^{L}+\Delta \tau^{L}\right)}{\left(1+\tau^{C}+\Delta \tau^{C}\right)}<1$

The impact of the CLS therefore acts to boost labor supply, output, consumption and investment. Unlike the CLS, the DBCFT continues to be non-distortionary in the presence of consumption and labor income taxes, but without a CIT. This is because, with infinitely-lived households, the introduction of the DBCFT does not distort the consumption or labor supply decisions and the same arguments made to explain Case 1 continue to hold.

However, when the CIT is non-zero, the introduction of a DBCFT generates distortions as the DBCFT interacts with the existing CIT to distort firms' investment and capital accumulation decisions. Carton and others (2017), pp.42, show that capital accumulation is distorted by the presence of both a DCBCFT and a CIT:

$R^{K}=\frac{\left(1-\tau^{D B C F T}\right)\left(1-\tau^{C I T}\right)}{\left(1-\tau^{D B C F T}-\tau^{C I T}\right)}\left[\frac{r}{\left(1-\tau^{C I T}\right)}+\delta\right]$

where $R^{K}$ is the rental rate of capital, $r$ is the risk-free interest rate and $\delta$ is the depreciation rate. Only in the case where $\tau^{C I T}=0$, that is when corporate income taxes are zero, is the DBCFT non-distortionary. Any increase in the DBCFT interacts with the CIT and acts to increase the rental rate of capital and hence lowers investment and the capital stock. Moreover, the higher the initial level of the CIT, the higher the interaction effect with the DBCFT.

The simulation with the DBCFT is meant to show that economic equivalence breaks and is hence illustrative. The interaction effect between corporate income and cash flow taxes is unlikely to occur in practice since the fiscal authorities are unlikely to use both taxes at the same time. Nonetheless, there may be situations where both types of taxes co-exist, notably in countries where taxation is levied by both the Federal or Central Government and State or Regional Governments. 
Figure 5: Equivalence for Case 1 When Initial Tax Rates Are Not Zero
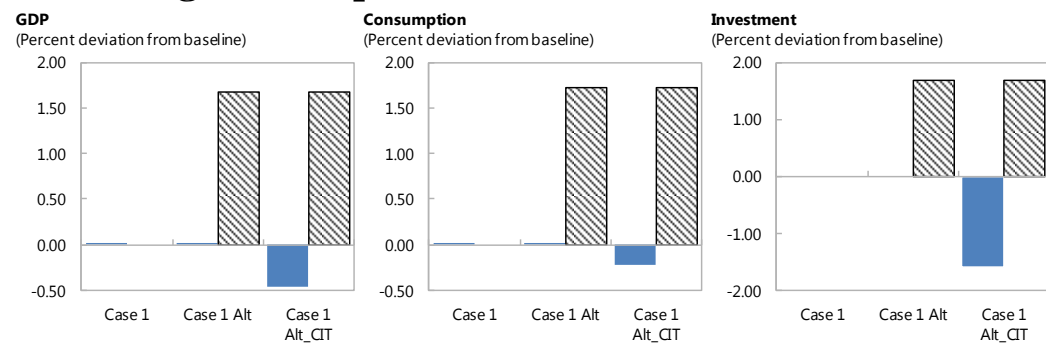

Current Account Balance/GDP

(Difference frombaseline)
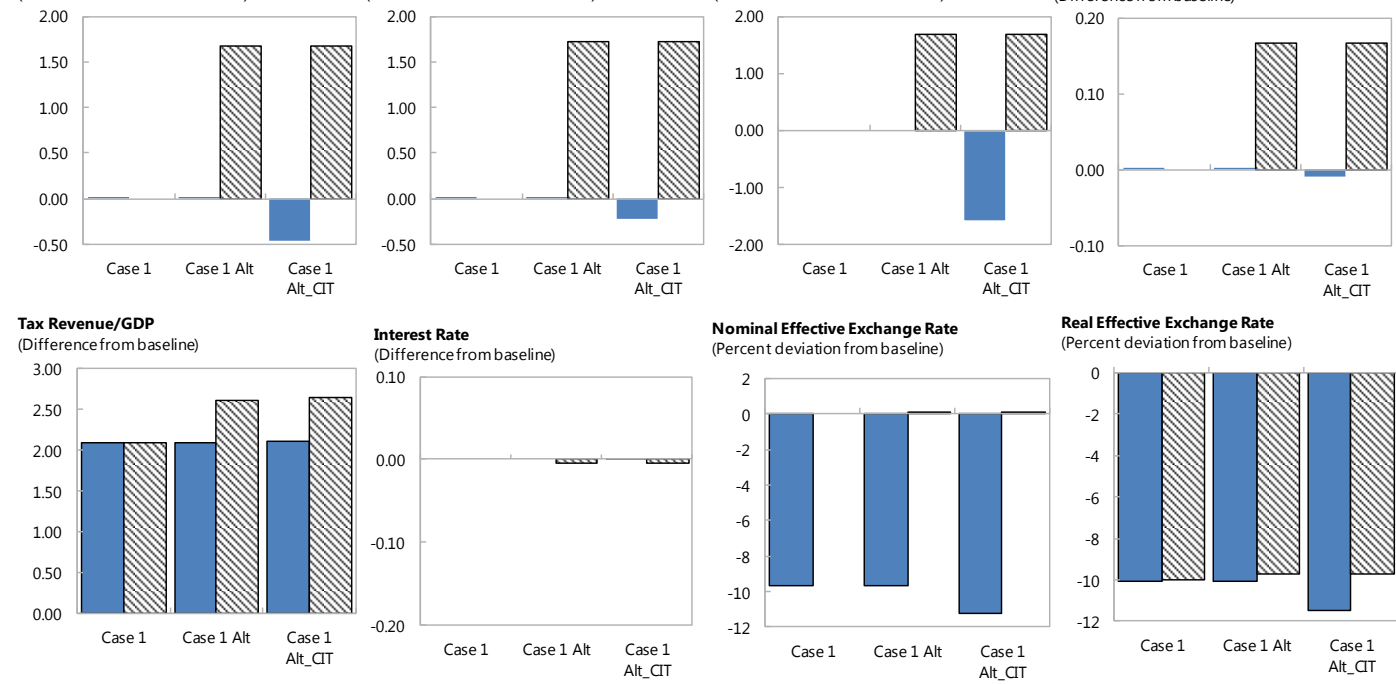

Source: GIMF simulations

\section{Conclusions}

This paper has examined the conditions under which destination-based cash-flow taxes and a combination of consumption taxes and labor income subsidies are equivalent. Using a simple overlapping generations model as well as simulations of GIMF, the paper illustrates that full equivalence between the two sets of taxes only occurs under very restrictive conditions. Equivalence holds only when there is no government expenditure (to achieve "tax revenue" equivalence) and when agents are infinitely lived and no existing taxes exist (to achieve "economic" equivalence). Deviations from those conditions break equivalence and imply that approximating destination-based cash-flow taxes as a combination of consumption taxes/VAT and labor income/payroll subsidies will not result in equivalent outcomes.

There are several implications stemming from these results. First, using a consumption tax plus labor income subsidy will not exactly approximate the impact of introducing a DBCFT. Second, as some of the simulations have shown, the impact on output stemming from an increase in consumption taxes together with a reduction in labor taxes can be greater than the impact of introducing a DBCFT. The reason for this result is that the consumption tax leads households to increase their savings and thereby reduce the real interest rate which boosts investment. ${ }^{21}$ This effect is not new and has been documented in the literature that has examined the impact of consumption taxes on economic growth (see for example Kaneko and Matsuzaki (2009)). Finally, and building on the previous point, earlier estimates of the

\footnotetext{
${ }^{21}$ The overall effect on real rates will be dependent on the size of the economy. The larger the economy, the greater the impact on global interest rates.
} 
benefits of a cash flow tax might have been overestimated in the sense that these were approximated by consumption taxes and labor income.

\section{REFERENCES}

Anderson, D., Hunt, B., Kortelainen, M., Kumhof, M., Laxton, D., Muir, D., Mursula, S. and S. Snudden (2013), "Getting to Know GIMF: The Simulation Properties of the Global Integrated Monetary and Fiscal Model", IMF Working Paper Series WP/13/55.

Ascari, G. and N. Rankin (2007) "Perpetual youth and endogenous labor supply: A problem and a possible solution”, Journal of Macroeconomics, Vol. 29, p.708-23.

Auerbach, A. J. (2017), "Demystifying the Destination-Based Cash-Flow Tax", Brooking Papers on Economic Activity (BPEA) Conference Drafts.

Auerbach, A. J., Devereux, M. P., Keen, M. and J. Vella (2017), "Destination-Based Cash Flow Taxation", Oxford University Centre for Business Taxation WP 17/01.

Benzell, S. G., Kotlikoff, L. J., and G. LaGarda (2017), "Simulating Business Cash Flow Taxation: An Illustration Based on the "Better Way" Corporate Tax Reform", NBER WP No. 23675.

Bernanke, B. S., M. Gertler, and S. Gilchrist (1999), "The Financial Accelerator in a Quantitative Business Cycle Framework," in: John B. Taylor and Michael Woodford, eds., Handbook of Macroeconomics, Volume 1C. Amsterdam: Elsevier.

Blanchard, O. (1985), "Debt, Deficits, and Finite Horizons", Journal of Political Economy, Vol. 93, pp. 223-247.

Brown, E.C. (1948), "Business Income Taxation and Investment Incentives", in Income, Employment and Public Policy, Essays in Honor of Alvin H. Hansen.

Carton, B., Fernandez-Corugedo, E. and B. Hunt (2017), "No Business Taxation without Model Representation: Adding Corporate Income and Cash Flow Taxes to GIMF", forthcoming IMF Working Paper.

Coenen, G., C. Erceg, C. Freedman, D. Furceri, M. Kumhof, R. Lalonde, D. Laxton, J. Lindé, A. Mourougane, D. Muir, S. Mursula, J. Roberts, W. Roeger, C. de Resende, S. Snudden, M. Trabandt, J. in't Veld (2010), "Effects of Fiscal Stimulus in Structural Models," American Economic Journal: Macroeconomics, Vol. 4(1), pp. 22-68.

Hall, R.E and A. Rabushka (1983), Low Tax, Simple Tax, Flat Tax, McGraw-Hill

Kaneko, A. and D. Matsuzaki (2009), "Consumption Tax and Economic Growth in an Overlapping Generations Model with Money Holdings", Journal of Economics, Vol. 98, pp.155-175. 
King, M. A. "The Cash Flow Corporate Income Tax," The Effects of Taxation on Capital Accumulation, ed. by Martin Feldstein. Chicago: UCP, 1987.

Kumhof, M. and D. Laxton (2007), "A Party Without a Hangover? On the Effects of U.S. Fiscal Deficits" IMF Working Paper Series, WP/07/202.

Kumhof, M. and D. Laxton (2009a), "Simple, Implementable Fiscal Policy Rules," IMF Working Paper Series, WP/09/76 (April 2009).

Kumhof, M. and D. Laxton (2009b), "Fiscal Deficits and Current Account Deficits," IMF Working Paper Series, WP/09/237.

Kumhof, M., D. Laxton, D. Muir and S. Mursula (2010), "The Global Integrated Monetary Fiscal Model (GIMF) - Theoretical Structure", IMF Working Paper Series, WP/10/34.

Meade Committee (1978), The Structure and Reform of Direct Taxation, report of a committee chaired by Professor J.E. Meade.

Yaari, M. (1965). "Uncertain Lifetime, Life Insurance, and the Theory of the Consumer." Review of Economic Studies. 32: 137-50. 


\section{APPENDiX A. A Simple MOdEL TO EXAM- INE EQUIVALENCE BETWEEN CFTS AND CLS}

This appendix explores the conditions under which the equivalence between a cash-flow tax (CFT) and consumption plus labor taxes (CLS) holds. The analysis is conduced in a tractable, closed economy, overlapping generations (OLG) model based on Ascari and Rankin (2007), AR henceforth. Contrary to the GIMF model, there is neither a capital stock nor rigidities, but the model includes real money balances.

Equivalence breaks with OLG households because they value government debt and money holdings. A CLS tax increases the consumption deflator and reduces the real value of government debt and money balances. Households want to increase their saving to rebuild their financial wealth, but without further investment, the real interest rate drops to restore equilibrium. This channel is absent with a CFT. When households are infinitely lived and do not value government debt or real money holdings, the same channel disappears entirely and the equivalence between CFTs and CLS is restored.

The presence of money in the utility function adds a further distortion brought about by consumption taxes which further breaks the equivalence between CFT and CLS (i.e. on top of the equivalence break induced by the OLG structure). This result has been reported in some monetary models like the one used in this paper (see eg Kaneko and Matsuzaki (2009) and references therein). This channel is not present in GIMF as money balances do not yield utility for households.

\section{A.1. Introducing Taxes into the Model and their Associated Tax Bases}

Before presenting the model, it is important to clarify how taxes on consumption, labor and the cash flow can be introduced into the model and how these affect the associated tax bases. The cash-flow tax base is unambiguous. However, a consumption tax (or a sale tax) can be defined on either the producer price $P$ or the consumer price $P^{c}$. Similarly, a labor tax or a payroll tax can be levied on the wage received by the household $W^{h}$ or the wage paid by the firm $W^{f}$.

Table 1. Tax Base Definition

\begin{tabular}{lcc} 
Tax name & Relative price & tax revenue \\
\hline consumption & $P^{c}=\left(1+\tau^{\mathrm{c}}\right) P$ & $\tau^{\mathrm{c}} P c$ \\
sales & $P=\left(1-\tau^{\mathrm{c}}\right) P^{c}$ & $\tau^{\mathrm{c}} P^{c} c$ \\
labor income & $W^{h}=\left(1-\tau^{\llcorner}\right) W^{f}$ & $\tau^{\llcorner} W^{f} l$ \\
payroll & $W^{f}=\left(1+\tau^{\llcorner}\right) W^{h}$ & $\tau^{\llcorner} W^{h} l$ \\
\hline
\end{tabular}


Table 1 proposes specific names to taxes on goods and services, depending on the tax base used to calculate it. If the tax base is the price received by the producer, the consumer must pay the tax on the top of the producer price and thus is labeled a consumption tax. If the tax base is the price paid by the consumer, the tax is paid "by the producer" who substracts it from the consumer price and is labeled sales tax. Specific names are also proposed for taxes on factors of production. If the tax base is the wage received by the households, the tax is paid by firms on top of the household wage and is labeled a payroll tax (firms hire labor). If the tax base is the wage paid by the firm, the tax is paid by households who must substract it from their labor income and is labeled labor income tax.

In the rest of the appendix, it is assumed that the tax on goods and services is a consumption tax and the tax on factors of production is a payroll tax such that

$$
P_{t}^{c}=\left(1+\tau_{t}^{\mathrm{C}}\right) P_{t}, \quad \quad \quad \quad \quad W_{t}^{f}=\left(1+\tau_{t}^{\mathrm{L}}\right) W_{t}^{h} .
$$

\section{A.2. Model}

The model introduces consumption, payroll and cash-flow taxes in AR which is a variant of the perpetual youth model first developed by Blanchard (1985). ${ }^{1}$ The presentation will focus on how different taxes are introduced and how these impact the equilibrium conditions.

The introduction of the payroll tax is motivated by the assertion that tax equivalence is between cash flow taxes and VAT and labor cost subsidies at the firm level (see Auerbach and others 2017, page 16). The labor income tax case is discussed below, since this is framework typically used in DSGE models, including GIMF.

Real variables are denoted by lower case and deflated by the producer price $P_{t}$, i.e. for variable $J$, $j_{s, t}=\frac{J_{s, t}}{P_{t}}$. Furthermore, the real wage is defined by

$$
w_{t} \equiv \frac{W_{t}^{h}}{P_{t}} \text {. }
$$

\section{A.2.1. Firms}

Each period, firms maximize after-tax profits which are given back to households as dividends, subject to a given technology where $l_{t}$ is labor and $y_{t}$ is output:

$$
\max _{l_{t}, y_{t}}\left(1-\tau_{t}^{\mathrm{CF}}\right)\left(P_{t} y_{t}-W_{t}^{f} l_{t}\right) \quad \text { s.t. } \quad y_{t}=l_{t}^{\alpha} .
$$

\footnotetext{
${ }^{1}$ The AR model is a tractable OLG model that can be used to show analytically that the equivalence between CFTs and CLS may not hold. Models that break Ricardian equivalence also break the equivalence between CFT and CLS. Adding capital (as in GIMF) amplifies the difference between the two types of taxes, as shown in the main text.
} 
The FOC for the firm reads

$$
\frac{W_{t}^{f}}{P_{t}}=\alpha l_{t}^{\alpha-1}
$$

With decreasing returns to scale, before-tax profits are positive and given by:

$$
D_{t} \equiv P_{t} y_{t}-W_{t}^{f} l_{t}=(1-\alpha) P_{t} y_{t}
$$

\section{A.2.2. Household decisions at the cohort level}

AR modify the Blanchard (1985)-Yaari (1965) model by considering Greenwood, Hercowitz and Huffman $(\mathrm{GHH})$ preferences and introducing real money balances. ${ }^{2,3}$ Agents have an exogenous probability of surviving into the next period, $q(0<q \leq 1)$, which is the only source of uncertainty in the model. To maintain a constant population, normalized to 1 , each period $1-q$ agents are newcomers replacing non-surviving households. The expected utility of the representative household in the cohort alive in period $n$ and born in period $s \leq n$ is:

$$
U_{s, n} \equiv \mathbb{E}_{n} \sum_{t=n}^{\infty}(\beta q)^{t-n} \ln \left(c_{s, t}^{1-\delta}\left(\frac{m_{s, t}}{1+\tau_{t}^{\mathrm{c}}}\right)^{\delta}-\eta \frac{l_{s, t}^{\varepsilon}}{\varepsilon}\right)
$$

where $c_{s, t}$ is real consumption of the representative household of the cohort born at $s, l_{s, t}$ its labor supply, and $m_{s, t}$ its real money balances (divided the real price of consumption, hence $\left.1+\tau_{t}^{\mathrm{C}}\right){ }^{4}$ $0<\beta<1,0<\delta<1, \varepsilon \geq 1$, and $\eta \geq 0$ are parameters. Real money balances enter the utility function in a complementary way with consumption, i.e. an increase in real money balances increases the marginal utility of consumption and thus labor supply.

The following definitions are useful:

$$
a_{s, t} \equiv c_{s, t}-z_{s, t}^{-\delta} \eta l_{s, t}^{\varepsilon}, \quad \text { (21) } \quad \text { where } \quad z_{s, t} \equiv \frac{m_{s, t}}{\left(1+\tau_{t}^{\mathrm{C}}\right) c_{s, t}}
$$

As in AR, $a_{s, t}$ is defined as "adjusted consumption" and $z_{s, t}$ as "money balances per unit of consumption". But in this case both $a_{s, t}$ and $z_{s, t}$ are themselves functions of the consumption tax and so any changes to the consumption tax will affect both $a_{s, t}$ and $z_{s, t}$ directly and indirectly (via their impact on consumption, money balances and labor).

Fiat money, $M$, and government bonds, $B$, are eligible to a life-insurance that pays a premium $\frac{1}{q}$ on eligible wealth to households surviving at period $t$. Conditional on its survival, the budget constraint for the household is:

$$
P_{t}^{c} c_{s, t}+M_{s, t}+B_{s, t}=\frac{1}{q}\left[M_{s, t-1}+\left(1+i_{t-1}\right) B_{s, t-1}\right]+W_{t}^{h} l_{s, t}+\left(1-\tau_{t}^{\mathrm{CF}}\right) D_{t}-T_{t}^{L S}
$$

\footnotetext{
${ }^{2} \mathrm{AR}$ introduce GHH preferences in order to ensure that finitely lived agents, who may accumulate too much wealth, do not have negative labor supply.

${ }^{3}$ The specification used by AR ensures that only labor supply and not money balances is wealth independent.

${ }^{4}$ This expression is equivalent to that one used by Kaneko and Matsuzaki (2009).
} 
where $T_{t}^{L S}$ denotes the net lump-sum taxes on households.

Real wealth at the beginning of period $t$ is defined by:

$$
v_{s, t-1} \equiv \frac{1}{q} \frac{M_{s, t-1}+\left(1+i_{t-1}\right) B_{s, t-1}}{P_{t}},
$$

so that the budget constraint can be re-expressed as:

$$
\left(1+\tau_{t}^{\mathrm{C}}\right) c_{s, t}+\frac{i_{t}}{1+i_{t}} m_{s, t}+q \mathbb{E}_{t}\left\{\frac{v_{s, t}}{1+r_{t}}\right\}=v_{s, t-1}+w_{t} l_{s, t}+\left(1-\tau_{t}^{\mathrm{cF}}\right) d_{t}-\tau_{t}^{L S}
$$

where, $\tau_{t}^{L S} \equiv \frac{T_{t}^{L S}}{P_{t}}$, and the real interest rate, $r$, is defined as:

$$
1+r_{t} \equiv\left(1+i_{t}\right) \frac{P_{t}}{P_{t+1}}
$$

Maximizing (19) subject to (24) yields the first order condition (FOC) for $c_{s}, b_{s}, l_{s}$ and $m_{s}$ which can be re-expressed as: ${ }^{5}$

$$
\begin{aligned}
\mathbb{E}_{t}\left\{a_{s, t+1}\right\} & =\beta \mathbb{E}_{t}\left\{\left(1+r_{t}\right) \frac{1+\tau_{t}^{\mathrm{c}}}{1+\tau_{t+1}^{\mathrm{c}}}\right\} a_{s, t} \\
\frac{1}{z_{s, t}} & =\frac{(1-\delta) i_{t}}{\delta\left(1+i_{t}\right)} \\
\frac{w_{t}}{1+\tau_{t}^{\mathrm{c}}} & =\frac{\eta}{1-\delta} z_{s, t}^{-\delta} l_{s, t}^{\varepsilon-1} .
\end{aligned}
$$

The FOCs are identical to those obtained by AR, with the exception of the consumption tax that appears in the Euler equation (an expected increase in the consumption tax acts like a decrease in the real interest rate) and the labor supply equation (a higher consumption tax reduces the purchasing power of labor income).

The consumption function for the representative household can be obtained by repeated substitution of the Euler equation for consumption and the intertemporal budget constraint (after solving forward) to yield:

$$
a_{s, t}=\frac{(1-\delta)(1-\beta q)}{1+\tau_{t}^{\mathrm{C}}} \omega_{s, t}-\frac{(1-\delta)(1-\beta q)}{1+\tau_{t}^{\mathrm{c}}} \mathbb{E}_{t} \sum_{i=0}^{\infty} q^{i} \rho_{t}^{t+i}\left[\frac{\eta\left(1+\tau_{t+i}^{\mathrm{c}}\right)}{1-\delta} z_{t+i}^{-\delta} l_{t+i}^{\varepsilon-1}\right]
$$

where $\rho$ is the iterated interest factor:

$$
\rho_{t}^{t}=1 \quad \text { and, for } i \geq 1, \quad \rho_{t}^{t+i}=\frac{1}{\left(1+r_{t}\right)\left(1+r_{t+1}\right) \cdots\left(1+r_{t+i-1}\right)},
$$

\footnotetext{
${ }^{5}$ These are conditional since they only apply if the agent is alive during the periods for which the conditions apply.
} 
and $\omega_{s, t}$ is lifetime wealth which is itself a function of financial wealth and lifetime income:

$$
\omega_{s, t} \equiv \underbrace{v_{s, t-1}+\mathbb{E}_{t} \sum_{i=0}^{\infty} q^{i} \rho_{t}^{t+i}\left[\left(1-\tau_{t+i}^{\mathrm{CF}}\right) d_{t+i}-\tau_{t+i}^{L S}\right]}_{\omega_{s, t}^{n h}}+\underbrace{\mathbb{E}_{t} \sum_{i=0}^{\infty} q^{i} \rho_{t}^{t+i} w_{t+i} l_{t+i}}_{\omega_{s, t}^{h}}
$$

where $\omega_{s, t}^{h}$ denotes human wealth and $\omega_{s, t}^{n h}$ is related to non-human wealth.

The consumption function for each cohort, (29), is affected by the consumption tax, such that higher levels of the tax result in lower levels of consumption. This is because higher consumption taxes erode the real value of wealth and hence lower consumption. All in all, the following observations based on the FOCs and the consumption function for each cohort can be made:

1. As in AR, the real money balance to consumption ratio of cohort $s, z_{s, t}$ and labor supply, $l_{s, t}$ are both cohort independent and therefore equal to their aggregate counterparts. This follows from (27) where the real money balance to consumption ratio is a function of the aggregate level nominal interest rate and the consumption tax, and (28) where labor supply is function of the real wage, consumption tax and real money balance to consumption ratio.

2. As in AR, increases in real money balances increase labor supply. This is because money balances are complements to consumption and an increase in money balances raises the marginal utility of consumption making it worthwhile for agents to work an extra hour.

3. Consumption taxes affect all of the FOCs for the household. They have both indirect and direct effects. They lower money balances per unit of consumption (indirect effect). They also "tilt" the Euler equation (26) since higher expected future consumption taxes increase consumption growth (and lower the current level of consumption). In (27), demand for real money balances increases, for a given level of consumption and interest rates, in response to higher consumption taxes. This is because money balances serve as a "medium of exchange" and higher consumption taxes increase the price of consumption thereby necessitating higher money balances to purchase a given level of consumption. Consumption taxes also affect labor supply, (28), by reducing the purchasing power of real wages, such that labor supply falls in response to higher consumption taxes. Overall, the impact of consumption taxes is therefore distortionary for households.

4. CFTs also affect households through their impact on non-human wealth, $\omega_{s, t}^{n h}$, such that higher CFTs lower non-human wealth and hence consumption. As (29) shows, CFTs are similar to lump-sum taxes, $\tau^{L S}$. As it will be shown below, the impact of the CFT will be dependent on the assumptions made about fiscal policy.

\section{A.2.3. Aggregate household behavior}

For any variable $x$, the relationship between aggregate per-capita and cohort-specific per-capita values is:

$$
x_{t}=(1-q) \sum_{s=-\infty}^{t} q^{t-s} x_{s, t}, \quad \text { (33) except for } \quad v_{t}=q(1-q) \sum_{s=-\infty}^{t} q^{t-s} v_{s, t} .
$$


Aggregate consumption at $t+1$ is the sum of the consumption of newcomers and households that remain alive:

$$
a_{t+1}=(1-q) a_{t+1, t+1}+q \sum_{s=-\infty}^{t}(1-q) q^{t-s} a_{s, t+1}
$$

Newcomers' consumption is different from aggregate consumption as they start with no financial wealth:

$$
a_{t+1, t+1}=a_{t+1}-v_{t}
$$

Already-alive households consumption between $t$ and $t+1$ evolves according to the Euler equation Equation (26). From (34), (35) and (26), the aggregate Euler equation is

$$
\mathbb{E}_{t}\left\{a_{t+1}\right\}=\beta \mathbb{E}_{t}\left\{\left(1+r_{t}\right) \frac{1+\tau_{t}^{\mathrm{C}}}{1+\tau_{t+1}^{\mathrm{C}}}\right\} a_{t}-\frac{(1-\delta)(1-\beta q)}{1+\tau_{t}^{\mathrm{C}}} \frac{1-q}{q} v_{t} .
$$

With infinitely lived households, $q=1$, the standard Euler equation for consumption holds, as the last term vanishes. This last term in the aggregate Euler equation accounts for the consumption discrepancy between exiting and newborn households, which implies all else equal, that expected aggregate consumption growth is lower relative to the infinitely lived representative agent case.

Consumption taxes affect the aggregate Euler equation in three ways. First, expected changes in consumption taxes, $\mathbb{E}_{t}\left\{\frac{1+\tau_{t+1}^{\mathrm{C}}}{1+\tau_{t}^{\mathrm{C}}}\right\}$, affect the slope of the Euler equation (the real interest rate discount factor), such that higher taxes in the future boost current consumption at the expense of future consumption. Second, the level of consumption taxes depresses the value of real wealth, resulting in lower consumption but increasing its growth rate. As shown below, this channel is crucial for breaking the equivalence between consumption/labor taxes and the CFT. Third, increases in consumption taxes lower $z_{t}$ and hence, all else equal, lower $a_{t}$.

\section{A.2.4. Government}

The introduction of the consumption, payroll and cash-flow taxes changes the government resource constraint relative to AR, which reads: ${ }^{6}$

$$
\begin{aligned}
B_{t}+M_{t}+T_{t}^{L S}+\left[\tau_{t}^{c}+\tau_{t}^{c f}\right] P_{t} y_{t}+ & {\left[\tau_{t}^{l}-\tau_{t}^{c f}\left(1+\tau_{t}^{l}\right)\right] W_{t} l_{t}=} \\
& \left(1+\tau_{t}^{c}\right) P_{t} g_{t}+\left(1+i_{t-1}\right) B_{t-1}+M_{t-1} .
\end{aligned}
$$

\footnotetext{
${ }^{6}$ The tax base for the consumption tax is $c_{t}=y_{t}-g_{t}$ and the expenditure on government consumption is $P_{t} g_{t}$. The differences appearing in the left hand side and the right hand side of the budget constraint exactly cancel out. Note further that for the purposes of the government's constraint, it does not matter if labor taxes are levied as payroll taxes (firms) or labor income taxes (households).
} 
The government constraint can be expressed in real terms as

$$
\begin{aligned}
\left(1+\tau_{t}^{c}\right) g_{t}-\tau_{t}^{L S}-\left[\tau_{t}^{c}+\tau_{t}^{c f}\right] y_{t}- & {\left[\tau_{t}^{l}-\tau_{t}^{c f}\left(1+\tau_{t}^{l}\right)\right] w_{t} l_{t}=} \\
& b_{t}-\left(1+r_{t-1}\right) b_{t-1}+m_{t}-m_{t-1} \frac{P_{t-1}}{P_{t}} .
\end{aligned}
$$

In the next section monetary and fiscal policy are described.

\section{A.3. General equilibrium}

Before considering the general equilibrium properties of the model and the impact of the new taxes, fiscal and monetary policies need to be specified. Since the purpose of this Appendix is to show conditions under which CFTs and CLS are equivalent, simple monetary and fiscal policies

are considered. As AR it is assume that government expenditure and nominal money balances are exogenous and constant over time. Likewise, consumption, payroll and cash-flow taxes will be treated as exogenous and constant over time. As in AR, government debt is treated as an independent policy instrument such that the stock of real debt is fixed exogenously:

$$
b_{t}^{\prime}=\left(1+r_{t}\right) b_{t}
$$

This leaves the lump-sum taxes, $\tau^{L S}$, as a residual.

\section{A.3.1. Labor market equilibrium}

Labor market equilibrium occurs when labor demand (17) is equal to labor supply (28):

$$
\alpha l_{t}^{\alpha-1}=\left(1+\tau^{l}\right) \frac{\varepsilon \eta\left(1+\tau^{c}\right)}{1-\delta}\left(z_{t}\right)^{-\delta} l_{t}^{\varepsilon-1}
$$

A solution for labor and output in terms of $z, \tau^{c}$, and $\tau^{l}$ can be derived:

$$
\begin{aligned}
l_{t} & =\left[\frac{\alpha(1-\delta)}{\varepsilon \eta\left(1+\tau^{l}\right)\left(1+\tau^{c}\right)}\left(z_{t}\right)^{\delta}\right]^{\frac{1}{\varepsilon-\alpha}}, \\
y_{t}=l_{t}^{\alpha} & =\left[\frac{\alpha(1-\delta)}{\varepsilon \eta\left(1+\tau^{l}\right)\left(1+\tau^{c}\right)}\left(z_{t}\right)^{\delta}\right]^{\frac{\alpha}{\varepsilon-\alpha}} .
\end{aligned}
$$

All else equal, higher payroll or consumption taxes are distortionary as they lower labor and hence output. Their overall impact on labor and output, however, will depend on their impact on the demand for real money balances, $z$. To do this it is important to look at the rest of the equilibrium in the model. Note further that cash flow taxes do not affect the equilibrium in the labor and product markets. 


\section{A.3.2. Goods market equilibrium}

Goods market equilibrium is given by:

$$
y_{t}=c_{t}+g_{t}
$$

which permits a solution for consumption in terms of government expenditure, taxes and real money balances:

$$
c_{t}=\left[\frac{\alpha(1-\delta)}{\varepsilon \eta\left(1+\tau^{l}\right)\left(1+\tau^{c}\right)}\left(z_{t}\right)^{\delta}\right]^{\frac{\alpha}{\varepsilon-\alpha}}-g_{t} .
$$

Consumption is also distorted by the presence of the consumption and payroll taxes. The following propositions can be made:

Proposition 1 (Economic equivalence). A necessary but not sufficient condition to mitigate the labor and output distortions emanating from consumption and payroll taxes is:

$$
\begin{aligned}
\left(1+\tau^{l}\right)\left(1+\tau^{c}\right) & =1 \\
\delta & =0
\end{aligned}
$$

which implies that positive consumption taxes must be offset by payroll subsidies and that households do not value real money balances.

Proof. Substitute (45) into (41), (42) and (44) to mitigate the direct distortions arising from the consumption and payroll taxes. By making $\delta=0$, money balances do not enter the households' utility function and so distortions arising from the consumption tax are also eradicated.

Note that (45) does not imply that the payroll subsidy should be set as the (negative) consumption tax rate, $\tau^{l}=-\tau^{c} .{ }^{7}$ Instead (45) implies that rates are related by:

$$
\tau^{l}=-\frac{\tau^{c}}{\left(1+\tau^{c}\right)}
$$

Proposition 2. Cash flow taxes do not distort labor or output.

Proof. The CFT does not enter any of the equilibrium conditions.

Proposition 3 (Revenue equivalence). A cash flow tax can generate the same revenue as consumption and payroll subsidies iff

$$
g_{t}=0
$$

and

$$
\tau^{c f}=\tau^{c}=-\tau^{l}
$$

\footnotetext{
${ }^{7}$ Note only in the case of the tax on labor falling on consumers would the condition, $\tau_{t}^{l}=-\tau_{t}^{c}$, hold. To see this note that the labor supply equation with consumption and labor income taxes ?? becomes

$$
w_{t}=\frac{\eta}{1-\delta}\left(\frac{1}{z_{t}}\right)^{\delta} l_{t}^{\varepsilon-1} .
$$
}


Proof. Substitute (43), (48) and (49) into the government's resource constraint (38) so that

$$
\begin{aligned}
\text { Tax revenue from CFT } & =\tau^{c f} y_{t}-\tau^{c f} w_{t} l_{t} \\
\text { Tax Revenue from CLS } & =\tau^{c} y_{t}-\tau^{c} w_{t} l_{t} .
\end{aligned}
$$

Taken together, propositions 1 - 3 are often used to motivate the equivalence between CFTs and CLS and suggest that both are non-distortionary. But note that implementing a policy where (49) holds, would not remove distortions in the output or labor markets. Hence:

Proposition 4 (Necessary Conditions for Revenue and Economic equivalence). A consumption tax and labor payroll subsidy cannot exactly replicate a cash flow tax so that matching revenue equivalence would not obtain economic equivalence and vice-versa.

Proof. Substituting (49) and (48) into (41), (42) and (44), yields:

$$
\begin{aligned}
l_{t} & =\left[\frac{\alpha(1-\delta)}{\varepsilon \eta\left(1-\tau^{c}\right)\left(1+\tau^{c}\right)}\left(z_{t}\right)^{\delta}\right]^{\frac{1}{\varepsilon-\alpha}}, \\
y_{t}=c_{t} & =\left[\frac{\alpha(1-\delta)}{\varepsilon \eta\left(1-\tau^{c}\right)\left(1+\tau^{c}\right)}\left(z_{t}\right)^{\delta}\right]^{\frac{\alpha}{\varepsilon-\alpha}} .
\end{aligned}
$$

Since $\left(1-\tau^{c}\right)\left(1+\tau^{c}\right)<1$, condition (49) would be, all else equal, expansionary for labor, output and consumption. Likewise substituting (47) and (48) into the government's resource constraint (38) would lead to the following amount of revenue:

$$
\begin{array}{ll}
\text { Tax revenue from CFT }= & \tau^{c f} y_{t}-\tau^{c f} w_{t} l_{t}, \\
\text { Tax revenue from CLS }= & \tau^{c} y_{t}-\frac{\tau^{c}}{1+\tau^{c}} w_{t} l_{t} .
\end{array}
$$

Since $\frac{\tau^{c}}{1+\tau^{c}}<\tau_{t}^{c f}$ the revenue from the cash flow tax is greater than that obtained from a consumption tax and labor subsidy.

Proposition 5 (No revenue equivalence redux). When government expenditure is different from zero, but (49) holds, the tax bases are different and will therefore not generate the same amount of tax revenue.

Proof. Take the government constraint and impose (49) so that the tax bases are different

Tax base from CLS: $\quad \tau^{c}\left(y_{t}-g_{t}\right)-\tau^{c} w_{t} l_{t}$

Tax base from CFT: $\quad \tau^{c f} y_{t}-\tau^{c f} w_{t} l_{t}$. 
All of these arguments are made from a partial equilibrium perspective and hold regardless of whether households are infinitely lived or not. To make further inroads, the exact general equilbrium must be considered, which will further show that with OLG households, imposing condition (45) will not restore economic equivalence.

\section{A.3.3. Asset market equilibrium}

The final equilibrium in the model pertains to the asset market, which is at the heart of economic equivalence, since consumption taxes distort the asset market equilibrium. Asset prices (interest rate) are determined by households' demand for government bonds and money balances and the government's supply of those assets. The aggregate Euler equation pins down the demand for government assets. Asset supply is given by the government's policies for money balances and government debt. Aggregate real wealth, $v$, is given by:

$$
v_{t}=\left(1+r_{t}\right) b_{t}+\mathbb{E}_{t}\left\{\frac{M_{t}}{P_{t+1}}\right\}
$$

which can be re-expressed, using (39) and the constancy of nominal balances $M_{t+1}=M_{t}=M$ as

$$
v_{t}=b^{\prime}+\mathbb{E}_{t}\left\{m_{t+1}\right\}
$$

with $m_{t+1}=M / P_{t+1}$. Equilibrium in the asset market is then given by (36) and (58):

$$
\beta \mathbb{E}_{t}\left\{\left(1+r_{t}\right)\right\} a_{t}=\mathbb{E}_{t}\left\{a_{t+1}\right\}+\frac{(1-\delta)(1-\beta q)}{\left(1+\tau^{c}\right)} \frac{(1-q)}{q} \mathbb{E}_{t}\left\{\left[b^{\prime}+m_{t+1}\right]\right\}
$$

This equation, together with the equilibrium in the labor and goods markets, plus assumed fiscal policies, determines the model's equilibrium. The equilibrium is a function of $z_{t}, z_{t+1}, \tau^{c}, \tau^{l}, g_{t}$, $g_{t+1}$ and $b^{\prime}$, where only $z_{t}$ and $z_{t+1}$, are endogenous variables. Since government expenditure is not central to claims about economic equivalence, it is assumed that $g_{t}=0$ at all times, as this simplifies the algebra and the exposition (see AR, page 716). To proceed further, take equation (59) and note that the real rate can be expressed as $\left(1+r_{t}\right)=\left(1+i_{t}\right) \mathbb{E}_{t}\left\{\left(\frac{m_{t+1}}{m_{t}}\right)\right\},{ }^{8}$ so the Euler equation can be re-expressed as:

$$
\beta\left(1+i_{t}\right) \frac{a_{t}}{m_{t}}=\mathbb{E}_{t}\left\{\frac{a_{t+1}}{m_{t+1}}\right\}+\frac{(1-\delta)(1-\beta q)}{\left(1+\tau^{c}\right)} \frac{(1-q)}{q} \mathbb{E}_{t}\left\{\left[\frac{b^{\prime}}{m_{t+1}}+1\right]\right\}
$$

\footnotetext{
${ }^{8}$ That is given that money growth determines producer price inflation.
} 
Using the following expressions:

$$
\begin{aligned}
m_{t+1} & =\left[\frac{\alpha(1-\delta)}{\eta \varepsilon\left(1+\tau^{l}\right)\left(1+\tau^{c}\right)}\left(z_{t+1}\right)^{\delta}\right]^{\frac{\alpha}{\varepsilon-\alpha}} z_{t+1} \\
\frac{a_{t}}{m_{t}} & =\frac{1}{z_{t}}\left(1-\frac{\alpha(1-\delta)}{\varepsilon\left(1+\tau^{l}\right)\left(1+\tau^{c}\right)}\right) \\
1+i_{t} & =\frac{(1-\delta) z_{t}+\delta \tau^{c}}{(1-\delta) z_{t}-\delta}
\end{aligned}
$$

implies that (60) can be written as

$$
\begin{array}{r}
\left(\frac{(1-\delta) z_{t}+\delta \tau_{t}^{c}}{(1-\delta) z_{t}-\delta}\right) \frac{\beta\left[\varepsilon\left(1+\tau^{l}\right)\left(1+\tau^{c}\right)-\alpha(1-\delta)\right]}{\varepsilon\left(1+\tau^{l}\right)\left(1+\tau^{c}\right) z_{t}}=\mathbb{E}_{t}\left\{\frac{\varepsilon\left(1+\tau^{l}\right)\left(1+\tau^{c}\right)-\alpha(1-\delta)}{\varepsilon\left(1+\tau^{l}\right)\left(1+\tau^{c}\right) z_{t+1}}\right\} \\
+\frac{(1-\delta)(1-\beta q)}{\left(1+\tau^{c}\right)} \frac{(1-q)}{q} \mathbb{E}_{t}\left\{\left[\begin{array}{c}
b^{\prime}\left[\frac{\alpha(1-\delta)}{\eta \varepsilon\left(1+\tau^{l}\right)\left(1+\tau^{c}\right)}\right]^{\frac{\alpha}{\alpha-\varepsilon}} \\
\left(z_{t+1}\right)^{1+\delta \frac{\alpha}{\varepsilon-\alpha}}
\end{array}\right]\right\}
\end{array}
$$

The following observations can be made:

Proposition 6 (CFTs non-distortionary). Cash flow taxes are non-distortionary and are equivalent to lump-sum taxes.

Proof. Cash flow taxes do not appear in any of the equilibrium conditions. They only appear in the government resource constraint.

The cash flow tax lowers firms' profits, but this additional tax revenue is rebated directly to consumers, so the cash flow tax is equivalent to a lump sum tax. The key proposition from this Appendix follows:

Proposition 7. The condition $\left(1+\tau^{l}\right)\left(1+\tau^{c}\right)=1$ which partly eliminates distortions in the labor and goods market is not enough to offset the distortions that arise in the asset market brought about by the consumption tax.

Proof. Set $\left(1+\tau^{l}\right)\left(1+\tau^{c}\right)=1$ in $(64)$ :

$$
\begin{aligned}
\frac{(1-\delta) z_{t}+\delta \tau^{c}}{(1-\delta) z_{t}-\delta} & \frac{\beta[\varepsilon-\alpha(1-\delta)]}{\varepsilon z_{t}}= \\
& \mathbb{E}_{t}\left\{\frac{\varepsilon-\alpha(1-\delta)}{\varepsilon z_{t+1}}\right\}+\frac{(1-\delta)(1-\beta q)}{1+\tau^{c}} \frac{1-q}{q} \mathbb{E}_{t}\left\{\left[1+\frac{b^{\prime}\left[\frac{\alpha(1-\delta)}{\eta \varepsilon}\right]^{\frac{\alpha}{\alpha-\varepsilon}}}{\left(z_{t+1}\right)^{1+\delta \frac{\alpha}{\varepsilon-\alpha}}}\right]\right\},
\end{aligned}
$$

so that distortions stemming from the consumption tax remain (see below for more). 
The following claim can be made:

Proposition 8 (Full economic equivalence). For consumption and payroll taxes to be nondistortionary (like CFTs) all of the following need to hold:

$$
q=1, \delta=0, \quad \text { and } \quad\left(1+\tau^{l}\right)\left(1+\tau^{c}\right)=1 .
$$

Proof. Setting $q=1, \delta=0$, in (65) yields a difference equation in $z$, independent of the level of consumption taxes:

$$
\mathbb{E}_{t}\left\{\frac{c_{t+1}}{m_{t+1}}\right\}=\beta \frac{c_{t}}{m_{t}}
$$

Proposition 9. For the taxes to raise the same amount of revenue requires (49) to hold too.

Note that if (66) holds, (49) will not, so that consumption and payroll subsidies do not raise the same amount of revenue.

As equation (65) makes clear, the presence of the consumption tax continues to distort the equilibrium in the model. The distortions arise in two places in the model. First, in the money balances demand equation, summarized by the right hand side of equation (65). As money serves as a medium of exchange, consumption taxes reduce the purchasing power of real money balances, implying that households have to hold additional balances to purchase consumption goods. This channel disappears from the model if households do not value money, that is, if $\delta=0$. Second, consumption taxes, erode the real value of financial wealth and require additional financial wealth to smooth consumption. This channel disappears when agents are infinitely lived, $q=1$.

To further understand the impact of consumption and payroll taxes in the model, the steady-state version of (65) is further examined with the aid of a Figure. Figure 6 below is a generalized expression of the equilibrium expression derived by $\mathrm{AR}^{9}$ which reads:

$$
\begin{aligned}
& \frac{\delta\left(1+\tau^{c}\right)}{(1-\delta) z-\delta}=\left(\frac{1}{\beta}-1\right) \\
+ & \frac{\varepsilon(1-\delta)\left(\frac{1}{\beta q}-1\right)(1-q)}{\left(1+\tau^{c}\right)(\varepsilon-\alpha(1-\delta))}\left[z+\left(\frac{\eta \varepsilon}{\alpha(1-\delta)}\right)^{\frac{\alpha}{\varepsilon-\alpha}} b^{\prime}(z)^{-\frac{\alpha \delta}{\varepsilon-\alpha}}\right] .
\end{aligned}
$$

As in AR, the LHS comes from the money demand equation, where money is a medium of exchange (ME) that facilitates transactions. This is represented in both panels in Figure 6 as the MET curve, where the T stands for the presence of taxes. Figure 6 also shows a ME schedule which assumes that consumption taxes are set to zero. Both curves slope downward since money balances are negatively related to the nominal interest rate. Note that the MET schedule has shifted

\footnotetext{
${ }^{9}$ Equation 25, page 716.
} 
upwards and to the right relative to ME schedule, as households require holding more money balances per unit of consumption at a given interest rate. Since the nominal interest rate is the price of money balances, the additional demand for money acts to increase the nominal interest rate. For ease of exposition all schedules that include taxes are dashed.

As AR, the RHS can be interpreted as giving the value for real rates consistent with the demand from financial wealth. It partly derives from the Euler equation $((36))$ which in the steady state is

$$
r=\left(\frac{1}{\beta}-1\right)+\frac{(1-\delta)\left(\frac{1}{\beta q}-1\right)}{\left(1+\tau^{c}\right)}\left(\frac{1}{q}-1\right) \frac{v}{a} .
$$

In the steady-state, a positive relationship between the real interest rate and financial wealth (per unit of adjusted consumption, $a$ ) exists. Financial wealth serves as a "store of value" by allowing agents to achieve their desired time profile for consumption (ie it allows consumers to smooth their marginal utility of consumption) for a given time profile for total income. Higher real rates increase the slope of the consumption path (it increases consumption growth) so that financial wealth is accumulated more rapidly when young and thereby resulting in a higher level of financial wealth for each cohort. Aggregating over individuals implies a higher level of financial wealth from existing households. The real value of financial wealth is reduced by the introduction of the consumption tax, thereby hampering the wealth accumulation process. To make up for it, households must accumulate even more wealth so that the additional household saving lowers the real interest rate. Since the RHS of (68) closely represents the "store of value" just described, Figure 6 labels the RHS of this equation as SVT, where the T stands for the presence of consumption taxes. The curve SV is also plotted, which assumes that consumption taxes are zero and is equal to the expression derived by AR. The right panel of Figure 6 also presents the lines SVT $(\mathrm{b}=0)$ and SV $(\mathrm{b}=0)$ which are the counterparts of SVT and SV when $b^{\prime}=0$. In this case, both curves are an upward-sloping straight line with a vertical intercept at $\frac{1}{\beta}-1$.

The overall impact of the consumption tax is that agents need to hold more real money balances and financial wealth. Increased demand for money bids up the interest rate, as shown by the outward shift in the ME to MET schedule. On the other hand, increased demand for financial wealth, has the opposite effect by lowering the interest rate. The overall effect on the interest rate is unclear and depends on the parameters of the model. What is clear however is that money balances are greater in the economy. 
Figure 6. Effect of the Consumption Tax

With positive government debt $\left(b^{\prime}>0\right)$

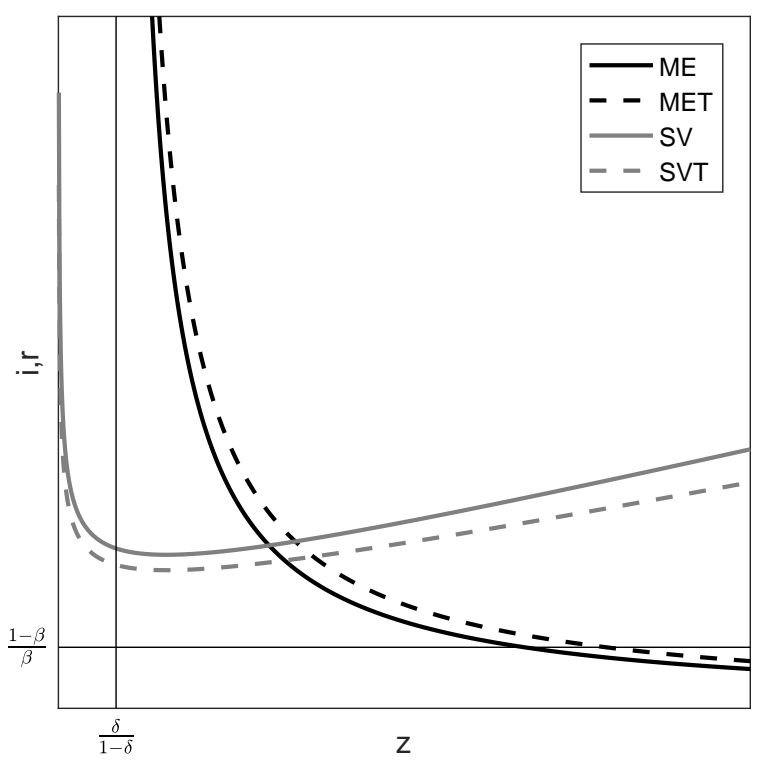

Without government debt $\left(b^{\prime}=0\right)$

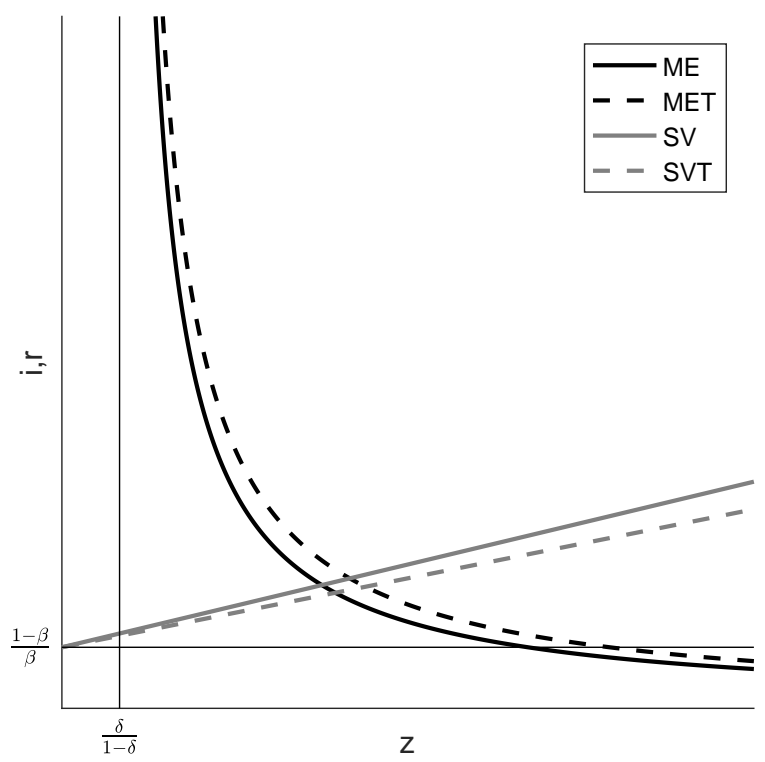

